\title{
Gentili and the Law of the Sea
}

Where are your monuments, your battles, martyrs?

Where is your tribal memory? Sirs,

in that grey vault. The sea. The sea

has locked them up. The sea is History. ${ }^{1}$

\subsection{Introduction}

In the Age of Exploration, which began in the early fifteenth century and lasted until the seventeenth century, European explorers, merchants, and adventurers began to travel the world by sea in search of new trading routes, riches, and knowledge. The exploration of distant lands and civilizations led to a sharp rise in global trade flows, diplomacy, and cultural interactions across the globe. The movement of people, goods, and ideas intensified dramatically during this era. ${ }^{2}$ Advancements in cartography and navigational instruments led to a new mapping of the globe, resulting in a new world-view. The world's seas and oceans served as bridges to growing interaction among different polities, linking them in dense webs of commercial and cultural exchange. ${ }^{3}$ From the perspective of many non-Europeans, though, the Age of Exploration meant the arrival of foreigners from previously unknown continents; the propagation of diseases that decimated populations; and exploitation, conquest, and war. Therefore, the age required a sustained reflection on how the law of nations regulated international cultural diversity, trade, and the world's oceans.

Yet, in the early modern period, the law of the sea (ius maris) remained vague, incomplete, and largely inconsistent. Only a few treaties addressed the law of the sea bilaterally and only then in a fragmentary fashion. In parallel, the

1 Derek Walcott, 'The Sea is History', in Derek Walcott, Selected Poems (London: Faber 2009).

2 David J. Bederman, 'The Sea', Bardo Fassbender and Anne Peters (eds.) The Oxford Handbook of the History of International Law (Oxford: Ou P 2012) 359-379, 359.

3 Andrew Phillips and J.C. Sherman, International Order in Diversity: War, Trade, and Rule in the Indian Ocean (Cambridge: CUP 2015) 51 and 59. 
existing customs addressed the issues inherent to the law of the sea only in a 'patchy' way, and the available treatises diverged significantly. As a result, the regulation of the world's oceans, that is, the main conduit of movement of peoples and transmission of goods and ideas at the time, remained a site of contestation. For nations and private actors alike (be they privateers, merchants, fishermen or sailors as well as adventurers and pirates), the law of the oceans was no more secure than the ocean itself. Were the oceans capable of being owned? ${ }^{4}$ If the answer to that question was yes, then, who owned the sea? Or, if ownership of the seas was materially impossible, could nations exercise any control over activity at sea such as rampant piracy and trade?

This chapter explores how Alberico Gentili addressed these key questions and in doing so contributed to the early modern development of the law of the sea. Such scrutiny is both timely and important, as the evolution of the law of the sea has contributed to shape world history over the past 500 years. Although Gentili's contribution to the law of the sea was original, significant, and foundational, it has been understudied and deserves further scrutiny. In order to discuss the Gentilian contribution to the law of the sea, this chapter examines both his De Iure Belli ${ }^{5}$ and the Hispanica Advocatio (or the Pleas of a Spanish Advocate). ${ }^{6}$

While international legal historians generally recognize De Iure Belli as Gentili's masterpiece, constituting a first attempt to systematize the law of war, they often criticize or dismiss the legal significance of the Hispanica Advocatio. They consider it as a work 'of forensic character and, as such, devoid of any coherent theoretical substance. ${ }^{7}$ Far from the theoretical heights of the De Iure Belli, the Hispanica Advocatio includes a range of apparently contradictory statements. ${ }^{8}$ Therefore, scholars question the significance of the Hispanica Advocatio to determine Gentili's stance on a range of maritime issues. In fact, the work is deemed to reflect advocacy rather than scholarly analysis, thus seeming less reliable than other sources.

4 Bederman, 'The Sea', 362.

5 Alberici Gentilis, De Iure Belli Libri Tres (Hanau: excudebat Guilielmus Antonius 1598); Alberici Gentilis, De Iure Belli Libri Tres, Thomas E. Holland (ed.) (Oxonii: Typographo Clarendoniano 1877); Alberico Gentili, De Iure Belli Libri Tres [1612] John C. Rolfe (transl.) (Oxford: Clarendon Press 1933).

6 Alberici Gentilis, Hispanicae Advocationis Libri Duo (Hanoviae: Apud haeredes Guilielmi Antonii 1613); Alberico Gentili, Hispanicae Advocationis Libri Duo, vol. II, Frank Frost Abbott (trans.) (New York: OUP 1921).

7 Diego Panizza, 'The Freedom of the Sea and the Modern Cosmopolis in Alberico Gentili's De Iure Belli' (2004) 30 Grotiana 88, 88.

8 Alain Wijffels, Alberico Gentili and Thomas Crompton (Leiden: Ius Deco 1992) (reporting these criticisms); G.H.J. Van der Molen, Alberico Gentili and the Development of International Law, 2nd edition (Leyden: A.W. Sijthoff 1968) 167, 173-174, 186. 
However, Gentili's De Iure Belli provides only a part of the Gentilian reflection on the law of the sea. After all, it was a treatise illustrating the law of war rather than the law of the sea. Therefore, it only peripherally dealt with the law of the sea, focusing on war-related issues. Instead, in the Hispanica Advocatio Gentili often narrated disputes involving important and delicate issues of international law in general and the law of the sea in particular. ${ }^{9}$ Therefore, it is crucially important to examine the Hispanica Advocatio to investigate the Gentilian theory of the law of the sea. In fact, not only can the work shed light on some sea-related aspects of the law of war, such as neutrality law, ${ }^{10}$ but it can also complement the sparse and fragmentary war-related maritime aspects of the De Iure Belli. ${ }^{11}$

Certainly, the Hispanica Advocatio has a significant place in the history and theory of international law. On the one hand, the Hispanica Advocatio has historical value, as it vividly portrays a number of legal disputes before the English High Court of Admiralty. It constitutes a time capsule of historical events at sea, revealing maritime state policies and the legal arguments presented by the parties to given maritime disputes of the day. It offers historical evidence of how different players - states and non-state actors, pirates and privateers, interlopers and merchants, belligerents and neutrals - interacted in times of war and peace. It also demonstrates how the early modern law of the sea was implemented in practice. On the other hand, the Hispanica Advocatio has a notable legal significance as it shows how litigation shaped the law of the sea. It depicts how general principles of law emerged in the heat of litigation and treaties were implemented in practice. More fundamentally, by showing conflicting arguments on given topical issues, the work illuminates the development of the international legal method. Certainly, as a work of advocacy, the Hispanica Advocatio needs to be interpreted carefully. With this proviso, such work can shed further light on the development of the early modern law of the sea, the development of an international legal method, and Gentili's seminal contribution to the history and theory of the law of the sea.

Additional primary sources on Gentili's contribution to the early modern law of the sea include the Gentili Papers and the private papers of Sir Julius Caesar. The Gentili Papers are conserved at the Bodleian Library; Manuscript D'Orville 608 contains fragmentary drafts of the Hispanica Advocatio and

9 Guido Astuti, 'Di un'Antica Raccolta di Questioni di Diritto Internazionale' (1938) 12 Annali della Facoltà Giuridica dell'Università di Camerino 215-248, 224.

10 See Chapter 5 above.

11 M.E. Nys, 'Les Manuscripts de Sir Julius Caesar' (1887) 19 Revue de Droit International et de Législation Comparée 461-471. 
some interesting personal documents. ${ }^{12}$ While for some parts, there seems to be a general concordance of Gentili's notes, as contained in MS D'Orville 608 and the Hispanica Advocatio, ${ }^{13}$ for other parts, 'the rearrangements carried out by Gentili were ... very extensive and may therefore warrant the provisional conclusion that the Hispanica Advocatio should be counted among the author's works of doctrine.'14

The private papers of Sir Julius Caesar (1557-1636), a judge of the High Court of Admiralty, include both correspondence with litigants, or lawyers, including Gentili, and Caesar's handwritten notes on the legal arguments presented by the parties. ${ }^{15}$ Of Italian descent-his father was one of the doctors of Queen Elizabeth I (1533-1603) —Caesar was a notable civilian and served as a judge of the High Court of Admiralty from 1587 until $1606 .{ }^{16}$ As noted by Wijffels, while 'Caesar's extensive notes as a judge' show 'a keen interest in counsels' technical arguments', they 'do not reflect any particular ambition for original thinking'; rather, they reflect the desire to buttress his own position. Caesar was probably 'a successful careerist who relied on a complex network of patronage', and 'succeeded, through his offices, his marriages, and private dealings, in accumulating considerable wealth and furthering his ... caree[r].17 The study of Caesar's papers can shed additional light on the functioning of the Court of Admiralty; the legal method used by counsels and judges; and the most salient arguments of key maritime disputes. As Gentili omits to give detailed information about the disputes in which he was involved in the Hispanica Advocatio, or even the Court's decision for that matter, ${ }^{18}$ the Caesar's Papers can fill some of the gaps. For instance, the Caesar's papers confirm that the 'civil law model of reasoning' prevailed at the Court of Admiralty. ${ }^{19}$ They show that the pleadings contained

12 MS D'Orville 608; Alain Wijjffels, 'Alberico Gentili e Thomas Crompton. Un Sfida tra un Professore e un Avvocato', in Alain Wijjffels (ed.) Alberico Gentili Consiliatore (Milan: Giuffrè 1999) $25-83,46$.

13 Keith R. Simmonds, 'The Gentili Manuscripts' (1959) 76 Zeitschrift der Savigny-Stiftung für Rechtsgeschichte 534-552, 550-551.

14 Wijffels, Alberico Gentili and Thomas Crompton, 7.

15 Alain Wijffels, 'Sir Julius Caesar's Notes on Admiralty Cases: An Alternative to Judicial Reporting?' in Chantal Stebbings (ed.) Law Reporting in England (London: Hambledon Press 1995) 89-112, 90.

16 Lamar M. Hill, Bench and Bureaucracy -The Public Career of Sir Julius Caesar (Cambridge: James Clarke \& Co. 1988) 1.

17 Alain Wijffels, 'Caesar, Sir Julius (bap. 1558, d. 1636)' ODNB (Oxford: OUP 2004) (noting that, like Gentili, Caesar lived lived in Bishopsgate and is buried in St. Helen's, Bishopsgate.); Hill, Bench and Bureaucracy, xiv.

18 Astuti, 'Di un'Antica Raccolta di Questioni di Diritto Internazionale', 228.

19 Wijffels, 'Sir Julius Caesar's Notes on Admiralty Cases', 97. 
reference to the fundamental texts and 'the ocean of doctrinal authorities' of the ius commune tradition. ${ }^{20}$ The sound archival work conducted by eminent historians has offered important insights that previous international law studies did not take into account ${ }^{21}$ and has clarified Gentili's stance on many maritime disputes. ${ }^{22}$

In addition to these primary sources, secondary legal, historical, and literary sources can close the gap in our knowledge of Gentili's contribution to the law of the sea. This 'triangulation' of the available sources helps filling the gaps in the primary sources, so that we may better understand and interpret Gentili's works and decipher his position on a number of legal issues, including maritime warfare and neutrality, piracy and privateering, plunder and prize. This 'triangulation' of the sources - the joint use of both primary sources and secondary legal, historical, and literary sources-also illuminates the impact that the Gentilian theory of the law of the sea had on the making of the early modern law of nations.

This chapter explores Gentili's contribution to the law of the sea. Its argument is divided into three parts. First, it discusses Gentili's approach to the spatial ordering of the sea and examines his twofold contribution to the conceptualisation of the freedom of the seas and the notion of the territorial sea in the early modern law of nations. Second, it investigates Gentili's approach to the regulation of the sea as a place where merchants, pirates, and privateers as well as other non-state actors interacted. In this regard, the chapter illuminates Gentili's view of these non-state actors and their role in the making of the law of the sea. In the sixteenth century, the oceans became a place of international encounter and conflict to an unprecedented degree because of the discoveries, the spread of maritime trade, and seaborne colonial expansion. ${ }^{23}$ The oceans became 'a space where the international community cease[d] to be an abstract idea, and bec[ame] real, in the interplay of the variety of different rights and duties which exist[ed] in the ocean space.' ${ }^{24}$ As Benton suggests, 'ships were

20 Wijffels, 'Sir Julius Caesar's Notes on Admiralty Cases', 92.

21 See e.g. Van der Molen, Alberico Gentili and the Development of International Law, 329 (noting that 'a thorough research into the disputes brought at the time before the English Admiralty Court could throw more light on Gentili's opinion'.)

22 For seminal studies of the same, see Alain Wijffels, 'Sir Julius Caesar and the Merchants of Venice' in F. Battenberg and F. Ranieri (eds.) Geschichte der Zentraljustiz in Mitteleuropa (Weimer 1994) 195-219.

23 Michael Kempe, 'Even in the Remotest Corners of the World: Globalized Piracy and International Law, 1500-1900' (2010) 5Journal of Global History 353-372, 354.

24 Henry Jones, 'The World as It is, Not as We'd like It to Be - Thinking with the Sea about International Law', (2015) 5 NYU Jean Monnet Working Paper Series, 1-30, 13. 
both 'islands of law ... and ... vectors of law thrusting into ocean space'.25 Reflection on the regulation of commerce, privateering, and piracy became crucial. ${ }^{26}$ Third, the chapter discusses the Hispanica Advocatio, scrutinising some maritime disputes in which Gentili served as counsel of Spain before the High Court of Admiralty. Discussion of the Hispanica Advocatio enables an exploration of how the law of the sea emerged in practice. In fact, admiralty courts 'dominated the ... development of international law at sea until, in the 2oth century, the United Nations Convention on the Law of the Sea (UNCLOS) attempted to settle finally the legal regime in a multilateral treaty'.27

The chapter proceeds as follows. Section 6.2 explores Gentili's dual contribution to the notion of the freedom of the seas and the concept of territorial waters. Section 6.3 examines Gentili's support for the freedom of communication, movement, and commerce. Section 6.4 discusses the difficult distinction between piracy and privateering in the early modern period, and Gentili's sanctioning of both. Section 6.5 discusses Gentili's advocacy at the High Court of Admiralty. After providing a critical assessment, the chapter concludes.

\subsection{The Sea: Between Freedom and Sovereignty}

Gentili's contribution to the early modern law of the sea was seminal, significant, and impactful. He played a fundamental role in the debate on the freedom of the seas, elaborating the diverging but complementary concepts of the freedom of the high seas and territorial waters and linking these notions to the concept of the balance of power. This section discusses the Gentilian elaboration of the binary concepts of the freedom of the seas and territorial waters, and the way Gentili shaped the legal debate on sea governance by exercising a key influence on its major players. This analysis shows how Gentili's theories influenced the development of the law of the sea in a previously unacknowledged way.

25 Lauren Benton, A Search for Sovereignty: Law and Geography in European Empires, 14001900 (Cambridge: CUP 2010) 112.

26 On the historical relation between world histories and the world's oceans, see Christian Buchet and Gérard Le Bouëdec (eds) The Sea in History-The Early Modern World/La Mer dans l'Histoire - la Période Moderne (New York: Boydell \& Brewer 2017) and David Armitage, Alison Bashford, and Sujit Sivasundaram (eds) Oceanic Histories (Cambridge: CuP 2017).

27 Henry Jones, 'Lines in the Ocean: Thinking with the Sea about Territory and International Law' (2016) 4 London Review of International Law 307-343, 311. 


\subsubsection{The Freedom of the High Seas}

In the age of European expansion, one of the main questions was whether the seas were free or open for appropriation and, in the latter case, who owned the seas. Roman sources established that the sea was common to all (res communis omnium), it had no owner, either public or private (res extra patrimonium), ${ }^{28}$ and was 'incapable of appropriation, just as [wa]s the air.' ${ }^{29}$ Roman sources also regarded the shore 'as a part of the sea, not as a part of the land' and considered it to be common to all. ${ }^{30}$ Nonetheless, under Roman law, the Emperor had jurisdiction over offences committed at sea, including piracy. ${ }^{31}$ In antiquity, such principles were not 'formal international law-because there were no States in the Mediterranean basin independent of the Roman Empire'; rather, they constituted 'basic public policy' of the Roman Empire until its fall. ${ }^{32}$ In the Middle Ages, a number of polities 'competed for supremacy over both land and water' in order 'to police adjacent seas', control fisheries, prevent piratical incursions, and secure 'exclusive control over trade routes'. 33

At the beginning of the seventeenth century, the battle of ideas concerning the freedom of the seas had reached its zenith. ${ }^{34}$ Far from being theoretical, the so-called 'Battle of Books' reflected the geopolitics of the time. ${ }^{35}$ On the one hand, since the fifteenth century, Spain and Portugal had advanced 'claims to sovereignty (including both jurisdiction and dominion) over ocean areas.' ${ }^{36}$ Since the 1493 Papal Bull Inter Caetera and the 1494 Treaty of Tordesillas divided the non-European world between Portugal and Spain, Spain had become the dominant maritime power in the Americas, while Portugal had established trading posts in South America, Africa, China, and the East Indies. ${ }^{37}$ The Spanish and Portuguese crowns 'treated all crossing these lines without their

28 Percy Thomas Jr. Fenn, 'Justinian and the Freedom of the Sea' (1925) 19 AJIL 716-727, 716 and $720-721$.

29 Id. 723.

30 Id.

31 Percy Thomas Jr. Fenn, 'Origins of the Theory of Territorial Waters' (1926) 20 AJIL 465-482, 465 .

32 Arvid Pardo, 'The Law of the Sea: Its Past and Its Future' (1984) 63 Oregon LR 7-17, 7.

33 Id.

34 W.E. Butler, 'Grotius and the Law of the Sea' in Hedley Bull, Benedict Kingsbury, and Adam Roberts (eds.) Hugo Grotius and International Relations (Oxford: OUP 1990) 209220, 211 .

Bederman, 'The Sea', 365 .

36 Id.

37 Jones, 'Lines in the Ocean', 4 (noting that the Treaty of Tordesillas drew an ideal line along a meridian west of the Cape Verde islands and gave Spain exploration rights to the west and Portugal to the east.). 
express permission as criminal intruders, no different from pirates'. ${ }^{38}$ Since the union of the Spanish and Portuguese crowns under King Philip II (1527-1598), the Iberians had claims to an almost universal jurisdiction over the entire globe. ${ }^{39}$

However, France, England, the Netherlands, Russia, and local rulers in Africa, South and South East Asia endorsed the principle of the freedom of the seas. ${ }^{40}$ In the aftermath of the Reformation, several European states 'refused to recognize the authority of the Pope to grant the non-European world to Spain and Portugal' and accorded no international validity to the Papal Bull. ${ }^{41}$ These nations accordingly 'demanded unlimited freedom of trade and free passage on the open seas', and 'defin[ed] every measure taken by Spain or Portugal to hinder such passage as itself an act of piracy'. ${ }^{42}$ Explorers, traders, and privateers from England, France, and the Low Countries openly challenged the Iberian dominion over the oceans. ${ }^{43}$ In parallel, for the Afro-Asian rulers, who governed over land-based empires, the oceans were 'a non-territory, a space not suitable for control, but rather one that existed solely as a transport surface. ${ }^{44}$

Against this background, Gentili endorsed the principle of the freedom of the high seas (mare liberrimum). ${ }^{45}$ For Gentili, the high seas were not susceptible to dominion and were rather common to all (res communis

$38 \quad$ Kempe, 'Globalized Piracy and International Law', 358.

39 Michel Bottin, 'Frontières et Limites Maritimes au Xvi ${ }^{\mathrm{e}}$ Siècle', in M. Lafourcade (ed) $L a$ Frontière des Origines à NosJours-Actes des Journées de la SocietéInternationale d'Histoire du Droit (Bourdeaux: Presses Universitaire de Bourdeaux 1998) 27-41, 37.

40 Hassan S. Khalilieh, Islamic Law of the Sea-Freedom of Navigation and Passage Rights in Islamic Thought (Cambridge: CUP 2019) (discussing the commonality of the sea in the Qur'an); Charles Alexandrowicz, An Introduction to the History of the Law of Nations in the East Indies (Oxford: Clarendon Press 1967) 42-49.

41 Pardo, 'The Law of the Sea: Its Past and Its Future', 9.

42 Kempe, 'Globalized Piracy and International Law', 358.

43 Edward P. Cheney, 'International Law under Queen Elizabeth' (1905) 20 English Historical Review 659-672, 659-66o (noting that when the pirate-merchant-adventurer Francis Drake (1540-1596) returned from his voyage round the world bringing with him plunder captured from Spanish settlements and ships, Don Bernardino Mendoza, the Ambassador of Spain in England, appealed directly to Queen Elizabeth for the restoration of stolen property. However, the Queen argued that Drake took legitimate reprisals against Spain because the Spanish monopoly was in breach of the law of nations (contra ius gentium). She did not recognize the authority of the Pope to invest the Spanish King with the Americas. Therefore, she concluded that 'all are at liberty to navigate that vast ocean, since the use of the sea and the air are common to all'.)

44 P.E. Steinberg, The Social Construction of the Ocean (Cambridge: CUP 2001) 46.

45 Gentili, De Iure Belli, Book I, Chapter 19, 146; Gentilis, Hispanica Advocatio, Book I, Chapter 6, p. 24; Chapters 8-9, 14, and 19. 
omnium) ${ }^{46}$ The sea was by nature open to all ... and its use [wa]s common to all, like that of the air. It c[ould] not therefore be shut off by any one., ${ }^{47}$ This was not a new idea; rather, in Roman law, the seas were res publica extra commercium, or public goods which could not be owned or traded. ${ }^{48}$ For Gentili, Roman law was not a binding source of the early modern law of nations; rather, it constituted a useful source of analogies as it often expressed natural justice. Gentili relied on the Roman conceptualization of the seas and transposed it to the early modern law of nations by way of analogy. He rejected the Iberian claims that the oceans were under the dominion of Portugal and Spain and closed to other nations. He also rejected the Republic of Venice's claims over the Adriatic Sea as a form of unlawful seizure (usurpatio). ${ }^{49}$ Rather, the freedom of the high seas entailed that all had the right to maritime navigation, trade, and free use (usus communis) of maritime resources (beneficia naturae). ${ }^{50}$

With regard to the use of maritime resources, for Gentili the sea was 'not a fit object for physical appropriation' and thus it was 'the property of none' (proprietas nullius) and instead 'common to all' and subject to 'common use..51 Nonetheless, what was taken from the sea ceased to be common property and became private property. ${ }^{52}$ As noted by Gentili, 'as the fish are caught, they unquestionably become the property of the owner into whose hands they have come ... and the very water of the sea, when it is collected for the manufacture of salt, belongs to [the person] who has collected it. ${ }^{53}$ Gentili nonetheless argued that property lost at sea should remain with the original owners. The regulation of ownership of the spoils of sunken ships that the ocean returned along the coasts was 'particularly contentious'. ${ }^{4}$ Who owned the cargo of the sunken ship? What compensation, if any, should be paid to those who helped

46 Gentili, Hispanica Advocatio, Book I, Chapter 4, p. 24 (mare communissimum); Gentilis, De Iure Belli, Book I, Chapter 19.

47 Gentili, De Iure Belli, Book I, Chapter 19, p. 90.

48 Bederman, 'The Sea', 362.

49 Gentili, De Iure Belli, Book I, Chapter 19, pp. 91-92.

5o Coleman Phillipson, 'The Great Jurists of the World-Albericus Gentilis' (1911) 12 Journal of the Society of Comparative Legislation 52, 62.

$5^{1} \quad$ Panizza, 'The Freedom of the Sea and the Modern Cosmopolis', 97-98.

52 Gentili, De Iure Belli, Book I, Chapter 4, p. 24; Diego Pirillo, 'Balance of Power and Freedom of the Seas: Richard Hakluyt and Alberico Gentili' in Daniel Carey and Claire Jowitt (eds) Richard Hakluyt and Travel Writing in Early Modern Europe (Aldershot: Ashgate 2012) 177-186, 184 .

53 Gentili, De Iure Belli, Book I, Chapter 4, p. 24.

54 Francesca Trivellato, 'Amphibious Power: The Law of Wreck, Maritime Customs, and Sovereignty in Richelieu's France' (2015) 33 Law \& History Review 915-944, 916. 
to salvage the cargo? Maritime customs provided 'rewards for those who helped salvage goods from a storm', for the right to compensation constituted an 'incentive to aid wrecked ships', even though such compensation 'varied greatly in rates and forms across time and place. ${ }^{55} \mathrm{~A}$ different albeit related issue was the regulation of items of cargo that reached the shore. Sovereign states soon adopted regulatory frameworks that complemented existing customs to govern the recovery of shipwrecks. The recovery of such wrecks was perceived to be a sensitive matter as it impinged on three key areas: the diplomatic relations with other sovereigns, 'the promotion of commerce and navigation, and the consolidation of royal power across the kingdom,.${ }^{56}$ Such norms had a liminal quality, located as they were at the intersection of multiple sources of law and subjected as they were to political impulses that responded to contingent situations. ${ }^{57}$ Gentili claimed that the property of shipwrecks should remain with the original owners; he criticized as 'unjust' the contemporary French and English law of salvage enabling those finding items at shipwrecks to keep their finds ('finders keepers'). ${ }^{58}$

At the heart of Gentili's reflections on the freedom of the sea was the distinction between dominion (dominium) and jurisdiction (iurisdictio), which has become a fundamental theme in the history and theory of the law of the sea. ${ }^{59}$ While he considered property claims to the sea to be inadmissible, he did admit that maritime nations could exercise different forms of jurisdiction over the high seas to prevent or punish crime and take measures against piracy. ${ }^{60}$ For Gentili, states had 'the right of supervision' and 'jurisdiction over the deep' to punish crimes committed at sea such as piracy. ${ }^{61}$ During Gentili's age, piracy constituted one of the greatest threats to the international legal order and the punishment of piracy was 'of the greatest importance'.62 Gentili saw pirates as the 'common enemies of humankind', who had placed themselves outside the legal order and thus did not enjoy any rights under the law of nations. ${ }^{63}$ Rather, they were subject to universal jurisdiction, and not only states

55 Trivellato, 'Amphibious Power', 918.

56 Id. 922 (referring to the Kingdom of France).

57 Id. 941.

58 Gentili, De Iure Belli, Book I, Chapter 19, p. 91.

59 Bederman, 'The Sea', $363-365$ (stating that while Roman sources distinguished the concepts of ownership (dominium), power (imperium), and control or jurisdiction (jurisdictio), in his De Iure Belli, Gentili revived the distinction between property and jurisdiction).

6o Alison Reppy, 'The Grotian Doctrine of the Freedom of the Seas Reappraised' (1950) 19 Fordham LR 243, 276.

61 Gentili, De Iure Belli, Book I, Chapter 19, p. 92; Book I, Chapter 25, p. 124.

62 Panizza, 'The Freedom of the Sea and the Modern Cosmopolis', 101.

63 Id. 
but also all individuals could punish them. ${ }^{64}$ As Gentili put it, 'a war against pirates justly calls all men to arms because of love for our neighbour and the desire to live in peace'.65 Yet, Gentili warned that such jurisdiction should not 'degenerate into abuse'.66 No nation should deny the use of the sea to another without good reason.

For Gentili, the denial of navigation and commerce 'without good and sufficient cause' constituted a violation of the law of nations and was thus an offence against the international community as a whole. ${ }^{67}$ Consequently, war could be justly declared to restore such rights. ${ }^{68}$ In fact, for Gentili, as the freedom of the seas enabled peoples to navigate, interact, trade, and acknowledge their unity (humanitatis nexus firmissimus), ${ }^{69}$ any disruption to the freedom of the seas (without good reason) would breach the law of nations. ${ }^{70}$

Finally, Gentili linked the debate on the freedom of the seas to the concept of the balance of power, as elaborated by Niccolò Machiavelli. ${ }^{71}$ For Gentili, the Spanish Empire threatened to jeopardize the balance of power both in Europe and beyond. In fact, 'under the pretext of prosecuting heresy, [the King of Spain] was pursuing [an] imperial plan'.72 Therefore, Gentili 'recommended following the policies of Lorenzo de' Medici', preserving the balance of power and preventing the establishment of one global dominion (monarchia universalis). ${ }^{73}$ On the one hand, he argued in favour of the freedom of the seas, to counter the hegemonic expansion of Spain; on the other, he also challenged the legal claims on which emerging empires sought to establish their dominion worldwide, by conceptualizing a range of limits to the freedom of the sea, including the notion of the territorial sea. ${ }^{74}$

\subsubsection{The Territorial Sea}

Gentili was the first to develop the notion of the territorial sea. Acknowledging that the coasts were 'not only geographical boundaries between the land and

\footnotetext{
64 Panizza, 'The Freedom of the Sea and the Modern Cosmopolis', 101.

65 Gentili, De Iure Belli, Book I, Chapter 25, p. 124.

66 Reppy, 'The Grotian Doctrine of the Freedom of the Seas Reappraised', 276.

67 Gentili, De Iure Belli, Book I, Chapter 4.

68 Reppy, 'The Grotian Doctrine of the Freedom of the Seas Reappraised', 276.

69 Gentili, De Iure Belli, Book I, Chapter 19.

70 Diego Pirillo, Filosofia ed Eresia nell'Inghilterra del Tardo Cinquecento—Bruno, Sidney, e i Dissidenti Religiosi Italiani (Roma: Edizioni di Storia e Letteratura 2010) 190.

71 Pirillo, 'Balance of Power and the Freedom of the Seas', 177.

72 Id. 180.

73 Id.

74 See Chapter 7 below.
} 
the sea', but they were 'often also political and jurisdictional frontiers', ${ }^{75}$ Gentili investigated the questions as to whether the adjacent waters belonged to the coastal state or could be subject to its jurisdiction. While Gentili reaffirmed that the sea was common to all and could not be appropriated, he nonetheless elaborated the concept of territorial waters as an intermediate legal notion between the freedom of the high seas and the territorial sovereignty of the coastal state. This section examines Gentili's seminal contribution to the law of the sea by focusing on how he elaborated the notion of territorial waters, relying on Roman law, civil law, and feudal law.

Under Roman law, the Emperor had some limited powers to police the seas; but such jurisdiction was essentially aimed at suppressing piracy and safeguarding the freedom of navigation and of commerce. ${ }^{76}$ Such jurisdiction was broad and narrow at the same time. It was broad because it related to the entire sea. It was narrow, because it was limited in scope, that is, the repression of piracy. It fundamentally differed from the power the Emperor exercised on land (terra firma). Therefore, the idea of 'a narrow belt of the sea' placed under coastal state sovereignty was not of Roman origin; ${ }^{77}$ rather, it was theorized after the fall of the Roman Empire when Venice and other Italian maritime cities advanced claims upon the Adriatic Sea and neighbouring waters respectively. ${ }^{78}$ Medieval jurists such as Baldus (1327-1400) elaborated the notion of adjacent waters out of feudal law, ${ }^{79}$ 'recogni[zing] ... the existence of a special interest of a monarch in the neighbouring waters, with an accompanying right of a more particularized jurisdiction than that monarch could exercise over the sea at large. 80

In the sixteenth century, there was no unitary notion of territorial seas; rather, various states advanced a series of claims, such as property rights or control over fisheries in their adjacent seas. ${ }^{81}$ For instance, the King of Denmark claimed dominion (mare clausum) in the northern seas, and alleged that he could forbid all fishing in the area and/or issue fishing licences. ${ }^{82}$ The English mathematician, astronomer, and maritime advisor to Queen Elizabeth I

\footnotetext{
75 Trivellato, 'Amphibious Power', 941.

76 Fenn, 'Origins of the Theory of Territorial Waters', 471.

77 Tommy T.B. Koh 'The Origins of the 1982 Convention on the Law of the Sea' (1987) 29 Malaya Law Review 1-17, 3.

78 Reppy, 'The Grotian Doctrine of the Freedom of the Seas Reappraised', 276-277.

79 Id. 276.

8o Fenn, 'Origins of the Theory of Territorial Waters', 473.

81 Umberto Leanza, 'La Delimitazione del Mare Territoriale nel Mare Mediterraneo' (1995) 16 Zb. Prav. Fak. Sveuc. Rij. 15-36, 30.

82 Cheney, 'International Law under Queen Elizabeth', 670
} 
John Dee (1527-1608) ${ }^{83}$ attempted to establish the legality of Elizabeth's claims of sovereignty over the surrounding seas and fisheries of the British Isles defining the boundaries of this dominion in the widest terms.${ }^{84}$ However, Elizabethan policy had generally allowed foreign access to British waters. ${ }^{85}$ Instead, soon after his succession to the English throne, James I of England (1566-1625) claimed 'all fisheries along the British coasts' thus 'prohibiting foreign vessels from fishing in those proximate waters without a royal licence. ${ }^{86}$ This policy extended the traditional Scottish policies of the closure of the sea (mare clausum) to the English sea. ${ }^{87}$ In his 1613 De Dominio Maris, the Scottish Professor of mathematics and of law William Welwood (1578-1622) argued that the adjacent seas were property of the coastal state. ${ }^{88}$ Welwood did not dispute freedom of passage over the oceans; rather, he was concerned with the 'exhaustibility of natural resources' ${ }^{89}$

Although Gentili believed that the sea was common to all (res communis omnium), he acknowledged that states had some limited powers to police thehigh seas. Nonetheless, that jurisdiction was essentially aimed at, and thus limited to, suppressing piracy and safeguarding freedom of navigation and of commerce. ${ }^{90}$ The jurisdiction over the high sea was therefore of more limited nature and scope than the power the sovereign exercised over land. In fact, while the former gave the sovereign the power to prevent and punish crimes, territorial sovereigny included both jurisdiction and imperium, that is, the power to govern a given space. If there were to be an extension of sovereignty to the adjacent sea, Gentili argued, then such power should be similar to that on land. In effect, there should be an extension of territorial sovereignty over the adjacent sea. ${ }^{91}$

83 John Dee, General and Rare Memorials pertaining to the Perfect Art of Navigation (London: John Day 1577).

84 David Armitage, The Ideological Origins of the British Empire (Cambridge: CUP 2000) 106-108.

85 Id. 108.

86 Bederman, 'The Sea', 369 .

87 Armitage, The Ideological Origins of the British Empire, 108 (noting that 'the Scots were more dependent on their fisheries than on their agriculture for subsistence, and hence more protective of their coastal and oceanic fishing grounds')

88 Ivan Shearer, 'Grotius and the Law of the Sea' (1983) 46 Bulletin of the Australian Society of Legal Philosophy 46-65, 52 .

89 Gary Edmond, 'The Freedom of Histories: Reassessing Grotius on the Sea' (1995) 2 Law Text Culture 179-217, 208.

9o Fenn, 'Origins of the Theory of Territorial Waters', 471.

91 Id. 
Gentili was the first to use the term 'territorial sea' or marine territory (marinum territorium) and he conceptualized the notion of territory (territorium) as a comprehensive concept covering both land and adjacent water. ${ }^{92}$ Gentili saw the territorial sea as a portion of the land (mare portio terrae) ${ }^{93}$ Coastal waters were, he argued, a part of the territory of the state whose shores they reached. It followed that the territorial rights of coastal states expanded to the sea adjacent to their coasts. Coastal states maintained regulatory powers and exclusive jurisdiction over their coastal waters (mare adiacens) for protecting vital interests such as state security, public health, and access to ocean resources. ${ }^{94}$ Such particularized jurisdiction existed in parallel with the general jurisdiction over piracy and criminal offences that all states had in the high seas. This was a breakthrough which helped to strengthen the internal and external sovereignty of states. ${ }^{95}$ 'Unlike his predecessors', Gentili 'assimilate[d] the land and the territorial waters into a single unit' in relation to the powers which the coastal sovereign could exercise over them. ${ }^{96} \mathrm{He}$ was the first to elaborate the legal notion of territory as including both land and waters.

With regard to the coastal state's power over the territorial sea, according to Gentili, such authority was not absolute; rather, it was subject to two limitations. First, coastal states were not to deny foreign ships innocent passage through their territorial waters. ${ }^{97}$ Second, foreign ships could freely use harbours for the purpose of obtaining shelter and provisions. ${ }^{98}$ Nonetheless, innocent passage remained a right provided that the state of transit ha[d] no reason to fear that harm w[ould] be done and if it [was] certain that harm [could] not be done. ${ }^{99}$ In fact, Gentili pointed out that states could legitimately refuse harmful passage: 'one who attempts what is unlawful loses his lawful

92 Gentili, De Iure Belli, Book III, Chapter 17, p. 384; Gentili, Hispanica Advocatio, Book I, Chapter 8 (entitled 'de territorio marino tuendo'); Fenn, 'Origins of the Theory of Territorial Waters', 478 (noting that 'After Gentili, it is literally correct to speak of territorial waters in international law'); Frank Frost Abbott, 'Alberico Gentili and His Advocatio Hispanica' (1916) 10 AJIL 737, 743; Leanza, 'La Delimitazione del Mare Territoriale nel Mare Mediterraneo', 21; Lauren Benton, 'Piracy and Politics in Gentili's Hispanica Advocatio: Implications for an Understanding of Universal Jurisdiction', in VvAA, Alberico GentiliGiustizia, Guerra, Impero (Milan: Giuffrè 2014) 169-188, 177.

93 Gentili, De Iure Belli, Book III, Chapter 17, p. 369 .

94 Id.

95 Bottin, 'Frontières et Limites Maritimes au XVI ${ }^{\mathrm{e}}$ Siècle', 30.

96 Reppy, 'The Grotian Doctrine of the Freedom of the Seas Reappraised', 278.

97 Gentili, De Iure Belli, Book I, Chapter 19, p. 86.

98 Gentili, Advocatio Hispanica, Book I, Chapter 6.

99 Gentili, De Iure Belli, Book I, Chapter 19, p. 87. 
rights'. ${ }^{100}$ Analogously, '[a]lthough the use of harbours [was] open to all'Gentili argued-'the abuse of them [was] not permitted to anyone.'101 For Gentili, warfare should not take place in the territory and adjacent sea of a neutral state. ${ }^{102}$ For instance, Gentili cited a case from the Dutch revolt against Spain, when a Dutch warship intercepted a Spanish warship leading to the United Provinces. When the Spanish warship took refuge in an English harbour, the Dutchmen waited for the Spaniards to leave the port. For Gentili, the conduct of the Dutch violated English sovereignty. ${ }^{103}$ Finally, in their territorial waters, states could deny rights of navigation and commerce for reasons of public health, national security, and self-defence. ${ }^{104}$ Gentili considered the Chinese practice of limiting commerce with foreigners to a limited number of ports to be legitimate.

The exact length of territorial waters remained unsettled until the second half of the twentieth century. ${ }^{105}$ Gentili did not take a definite position on the extent of the territorial waters. Three main criteria were used in maritime practice: the cannon-shot rule, the line-of-sight rule, and marine leagues. ${ }^{106}$ First, the cannon-shot rule set the limit of the extent of territorial waters to the reach of a shot fired from the coast. ${ }^{107}$ Second, under the line-of-sight rule, 'a coastal state could claim a band of the sea from its coast to as far as the human eye could see, within which, the coastal state could exercise powers to protect its security, to enforce its customs regulations, and to protect the coastal population and its economic interests, for example, in fisheries.108 Third, marine leagues were sometimes used to identify the extent of territorial waters. Both the cannon-shot rule and the line-of-sight rule were vague; a more certain criterion for identifying the territorial sea was given by the use of marine league, corresponding to four nautical miles. ${ }^{109}$ In the Hispanica Advocatio Gentili seems to adhere to the 100-mile boundary rule established by medieval

\footnotetext{
100 Gentili, De Iure Belli, Book I, Chapter 19, p. 87.

101 Gentili, Hispanica Advocatio, Book I, Chapter 14, p. 61.

102 Id.

103 Abbott, 'Alberico Gentili and His Advocatio Hispanica', 744.

104 Gentili, De Iure Belli, Book I, Chapter 19.

105 Trivellato, 'Amphibious Power', 915; Leanza, 'La Delimitazione del Mare Territoriale nel Mare Mediterraneo', 21; United Nations Convention on the Law of the Sea (UNCLOS) opened for signature on 10 December 1982, in force 16 November 1994, 21 ILM 1261 (1982), Article 2 (setting the limit of territorial waters to twelve nautical miles).

106 Koh, 'The Origins of the 1982 Convention on the Law of the Sea', 4.

107 Id.

108 Id.

109 Id.
} 
glossators. ${ }^{110}$ Nonetheless, since this was a piece of advocacy, it remains uncertain whether by using this criterion he expressed his definitive stance on the matter.

\subsubsection{Impact}

What impact did Gentili's theory of the freedom of the high seas and territorial waters have on the development of the early modern law of the sea? Treatises on international law rarely mention Gentili when they discuss the so-called battle of the books. After all, Gentili did not author a specific treatise on the freedom of the seas or on territorial waters. Rather, his contribution to the theory of the law of the sea is 'hidden' in his more general works, De Iure Belli and the Hispanica Advocatio. Nonetheless, this section shows that his contribution has been more influential and impactful than it is usually acknowledged. The Gentilian theory of the freedom of the seas and the conceptualization of the territorial sea certainly inspired subsequent theoretical and practical developments. Not only did Gentili deeply influence the main proponent of the freedom of the seas, Hugo Grotius $\left(1583^{-1645)}\right)^{111}$ but he also influenced the principal proponent of the closure of the sea (mare clausum), notably John Selden (1584-1654). ${ }^{112}$

On the one hand, Gentili strongly influenced the main proponent of the freedom of the sea, Hugo Grotius. Grotius read Gentili's works and recommended them to his students. Reportedly, Grotius had both De Iure Belli and Hispanica Advocatio among his books and there is evidence that he read both. ${ }^{113}$ In his 1609 Mare Liberum, Grotius mentioned Gentili among the most famous jurists (clarissimi iurisconsulti) favouring a universal right to navigation. ${ }^{114}$ Following Gentili, Grotius argued that the high seas were common to all (res communis omnium) and could not be acquired (res extra commercium).

110 Fenn, 'Origins of the Theory of Territorial Waters', 477 (noting that in his Tractatus de Fluminibus, Bartolus of Saxoferrato (1314-1357) argued that state sovereignty extended to nearby islands that were at a 'moderate distance' from the coast not exceeding 100 miles. Later jurists cited this passage to lay down a hundred-mile limit to the jurisdiction of a state over the adjoining sea.)

111 Hugonis Grotii, Mare Liberum sive de Iure quod Batavis Competit ad Indicana Commercia Dissertatio (Leiden: Elzevier 16og); Hugo Grotius, The Free Sea, David Armitage (ed.), Richard Hakluyt (trans.), (Indianapolis: Liberty Fund 2004).

112 John Selden, Of the Dominion, Or, Ownership of the Sea (London 1652).

113 Pirillo, 'The Balance of Power and the Freedom of the Seas', 183; Lauren Benton, 'Legalities of the Sea in Gentili's Hispanica Advocatio', in Benedict Kingsbury and Benjamin Straumann (eds.) The Roman Foundations of the Law of Nations (Oxford: OUP 2010) 269-282, 281.

114 Diego Pirillo, 'Eretici Italiani e Selvaggi Americani: il Nuovo Mondo nella Coscienza Protestante Italiana del Cinquecento' (2010) 5o Rinascimento 377-397, 389. 
Rather, every nation was free to travel to every other nation, and to trade with it. ${ }^{115}$ Grotius also recognized the difference between proprietary rights and the authority to assert jurisdiction offshore, 'a legal distinction for which he cite[d] Baldus but for which he $\mathrm{m}$ [ight] have been in Gentili's intellectual debt'.116 However, his theory profoundly differed from Gentili's in a number of ways. For example, whereas Gentili linked the freedom of the seas to the idea of the balance of powers, Grotius did not make this connection. And while Gentili's positions on the freedom of the high seas and the notion of territorial waters in part reflected and influenced the Elizabethan and Jacobean policies, by claiming the freedom of the sea, Grotius provided an ideological justification of 'Dutch interloping in the colonial empires of Spain and Portugal'.17

On the other hand, the Gentilian concept of territorial waters influenced the main proponent of the closure of the sea, the lawyer and polymath John Selden. In his Mare Clausum (Closed Seas), ${ }^{118}$ written under royal patronage in 1616/1617 but published only in 1635 for contingent political reasons, Selden argued that the sea could be appropriated. Selden's theory thus differed from the Gentilian one. ${ }^{119}$ Like Gentili, though, Selden admitted innocent passage in the adjacent sea, ${ }^{120}$ and maintained that restrictions on navigation and commerce did not necessarily violate the law of nature and the law of nations. ${ }^{121}$

The Gentilian theory of the freedom of the high seas and his conceptualization of the territorial sea relied on maritime practice. When the King of Denmark claimed dominion in the northern seas and alleged that he could prohibit fishing in the area and/or issue fishing licences, the English responded that 'the most celebrated lawyers [Gentili] had given their judgment that the sea, by the law of nations, [was] free and common, and [could] not be monopolized by any prince.'.22 Since James I's ascension to the English throne in 1603, England advanced claims over the seas around England and Scotland. ${ }^{123}$

\footnotetext{
115 See generally Grotius, The Free Sea.

116 Bederman, 'The Sea', 366; Grotius, The Free Sea David Armitage (ed) Richard Hakluyt (trans) 31 ('[Some] affirm a right over the sea [based on] protection and jurisdiction, which ... they distinguish from property'.)

117 Martine Julia Van Ittersum, Profit and Principle: Hugo Grotius, Natural Rights Theories and the Rise of Dutch Power in the East Indies, 1595-1615 (Leiden: Brill 2006) xix.

118 Selden, Of the Dominion, Or, Ownership of the Sea.

119 Butler, 'Grotius and the Law of the Sea', 211.

120 Ruth Lapidoth, 'Freedom of Navigation its Legal History and its Normative Basis' (1975) 6 Journal of Maritime Law \& Commerce 259, 266.

121 Edward Gordon, 'Grotius and the Freedom of the Seas in the Seventeenth Century' (2008) 16 Willamette JIL \& Dispute Resolution 252-269, 266.

122 Cheney, 'International Law under Queen Elizabeth', 670.

123 Pirillo, 'Balance of Power and the Freedom of the Seas', 185.
} 
Therefore, Gentili's reflection contributed to the development of the early modern law of the sea.

More fundamentally, Gentili's extravagant words would become a commonplace during the following century. By the end of the seventeenth century, the principle of the freedom of the high seas prevailed. This reflected the 'power politics of the period, as the principle of the freedom of the seas matched the rising of maritime powers (especially Britain, the Netherlands, and France) at the expenses of coastal states. ${ }^{124}$ Nonetheless, the law of the sea gradually accommodated both the ideas of open and closed seas, acknowledging the right of coastal states to exercise some exclusive prerogatives in their territorial waters. ${ }^{125}$ Gentili's concept of the territorial sea was generally adopted, as states increasingly recognized 'a range of authority over navigation and fisheries very close to shore.' ${ }^{126}$

While the freedom of the high seas could be 'a device for universal justice' as it formally granted all states equal access to the seas, 'in practice, ... it open[ed] possibilities only for those who ha[d] the means of making use of the opportunity', thus 'serv[ing] the interests of the rich and powerful'. ${ }^{127}$ According to Röling and Anghie, the thesis of the freedom of the seas 'made it possible for European states to conquer and dominate the greater part of the non-European world.' ${ }^{128}$ Such theory structured the world around expansionist, capitalist, and imperialist exploitation. ${ }^{29}$

Yet, the theory of mare clausum was no better alternative. In fact, it presupposed the hegemony of the Iberian states, and it favoured imperial claims to universal dominion over the entire world and the establishment of a universal monarchy (monarchia universalis). It would preclude freedom of commerce and navigation in areas of the globe where such freedoms had been exercised for centuries. ${ }^{130}$ While the Grotian theory of the freedom of the sea perfectly matched and represented the interest of the Dutch East India Company,

\footnotetext{
124 Bederman, 'The Sea', 369.

125 Gordon, 'Grotius and the Freedom of the Seas in the Seventeenth Century', 268.

126 Bederman, 'The Sea', 369 .

127 B.V.A. Röling, 'Are Grotius' Ideas Obsolete in an Expanded World?', in Hedley Bull, Benedict Kingsbury, and Adam Roberts (eds), Hugo Grotius and International Relations (Oxford: Clarendon Press 1990) 281-299, 282.

128 Id. 295 .

129 Anthony Anghie, Imperialism, Sovereignty, and the Making of International Law (Cambridge: CUP 2005).

130 Ran Anand, Origin and Development of the Law of the Sea (The Hague: Martinus Nijhoff 1982) 86 (arguing that the principle of the freedom of the seas was well-established in the Indian Ocean before the arrival of Europeans).
} 
Gentili's theory of the freedom of the seas and his conceptualization of the territorial sea reflected (and influenced) British policies.

Yet, by linking the freedom of the seas to the balance of power, the Gentilian theory expressed the need for an equilibrium among states against hegemonic attempts to establish empires. More generally, Gentili conceptualized the freedom of the high seas and the territorial sea not as mutually exclusive concepts, but as complementary ones. The Gentilian concept of the freedom of the sea was not unlimited; rather, it was subject to some important considerations, such as the prevention of crime and piracy, and the maintenance of peace. In parallel, the jurisdiction and regulatory power that coastal states exercised over territorial waters were not absolute; rather, Gentili envisaged the right of innocent passage in territorial waters, thus limiting the powers of the coastal states. Overall, the Gentilian theory was characterized by moderation and the perceived need to strike a balance between opposing interests. His idea of the balance of powers and his anti-hegemonic stance highlighted a fundamental feature of the law of the sea: the need to balance the interests of coastal states and those of the international community as a whole ${ }^{131}$ to prevent maritime powers from reaching hegemony and ensure peaceful, prosperous, and just relations among nations. The Gentilian binary theory of the freedom of the seas and territorial waters remains embedded in the current law of the sea. ${ }^{132}$ The enduring consequence of the seventeenth-century debate over the freedom of the seas and Alberico Gentili's role in it was the gradual emergence of an inclusive ocean regime 'to govern humanity's common interest in the use of shared space, shared resources, and a shared destiny' ${ }^{\prime} 33$

\subsection{The Freedom of Communication, Movement, and Commerce}

Relying on the Stoic notion of universal human society, Gentili conceptualized the world as the great commonwealth of humankind (respublica magna).134 He viewed the world as a cosmopolis, a city inhabited by people from many different countries, free to reach, interact, and trade with one another. For Gentili, 'nature has established among men kinship, love, kindliness, and a

\footnotetext{
131 Arthur Nussbaum, A Concise History of the Law of Nations (New York: Macmillan 1954) 99. 132 Gentili, De Iure Belli, Book I, Chapter 19, p. 91 ('community of ownership must be observed in all things which nature has produced for the common use of [human beings]'); Diego Panizza, "The "Freedom of the Sea" and the "Modern Cosmopolis", in Alberico Gentili's De Iure Belli' (2009) 30 Grotiana 88-106, 97.

133 Gordon, 'Grotius and the Freedom of the Seas in the Seventeenth Century', 269.

134 Panizza, 'The Freedom of the Sea and the Modern Cosmopolis', 88.
} 
bond of fellowship: ${ }^{135}$ Because of the natural interdependence of nations, nature itself required the freedom of the seas (mare liberum), freedom of interaction (ius communicationis), freedom of movement (ius peregrinandi), and freedom of commerce (ius commercii). ${ }^{136}$ Only through navigation, interaction, and trade could the citizens of the world reach each other. ${ }^{137}$ Each freedom became a natural right that was part and parcel of the system of natural law (ius humanae societatis) and closely connected to the other freedoms. ${ }^{138}$ For instance, Gentili highlighted the close relationship between freedom of commerce and freedom of the sea. On the one hand, the freedom of the sea was instrumental to the freedom of international commerce. ${ }^{139}$ On the other hand, merchants ought to enjoy the freedom of the sea to serve the common good. While sections 6.1 and 6.2 examined the Gentilian conceptualization of the freedom of the sea-as qualified by the theory of the balance of power-and the concept of territorial waters respectively, this section illuminates the Gentilian theory of freedom of communication, freedom of commerce, and freedom of movement as well as their qualifications and limits. Far from positing these as absolute rights, Gentili elaborated a sophisticated legal framework that attempted to strike a balance both between the interests of states and those of the international community and also between the safeguarding of cultural diversity and early modern globalization.

\subsubsection{The Freedom of Communication}

The freedom of communication (ius communicationis) meant the freedom to interact with other people, to share or exchange goods and ideas, participate in the world, and cooperate for the common good. ${ }^{140}$ Although sovereign nations constitute perfect communities in themselves (civitas perfecta, or respublica sibi sufficiens), they are never so self-sufficient that they do not require some mutual assistance, association, and intercourse with other countries. ${ }^{141}$ Their

135 Gentili, De Iure Belli, Book I, Chapter 15, p. 67.

136 Panizza, 'The Freedom of the Sea and the Modern Cosmopolis', 88.

137 Id. 92.

138 Gentili, De Iure Belli, Book I, Chapter 19, p. 138.

139 K.R. Simmonds, 'Alberico Gentili and the Admiralty Bar, 1605-1608' (1958) 7 Archiv des Völkerrechts 3-23, 8 .

140 Luigi Lacchè, 'Introduzione' in Luigi Lacchè (ed) Ius Gentium, Ius Communicationis, Ius Belli-Alberico Gentili e gli Orizzonti della Modernità (Milano: Giuffrè 2009) 7 .

141 Georg Cavallar, The Rights of Strangers: Theories of International Hospitality, the Global Community, and Political Justice since Vitoria (London: Routledge 2002) 395; Luca Scuccimarra, 'Societas Hominum. Cosmopolitismo Stoico e Diritto delle Genti', in Lacchè (ed) Ius Gentium, Ius Communicationis, Ius Belli 40-41. 
citizens are both citizens of their home country and of the world. They belong to the universal society of humankind (civitas mundi) and have certain natural rights. The right of communication was grounded in the natural sociability of humankind. ${ }^{142}$ As Vitoria put it, 'it is a law of nature to welcome strangers' because of amity (amicitia) and kinship between human beings (hominum inter se cognatio).'143 For Vitoria, 'a man is not a wolf to his fellow man ... but a fellow.' 144

Addressing the ius communicationis was of extraordinary importance to the development of the early modern law of nations. Not only was the freedom of communication the substratum of all the other freedoms, but it was perceived as an expression of human sociability and kinship and as such at the very core of the law of nations. In this sense, the right of communication constituted 'the raison d'être of international law as a whole. ${ }^{145}$ Ancient principles confirmed a pattern of free movement through history. ${ }^{146}$ Yet, hospitality became a particular concern in the sixteenth century due to the growth of migratory flows during the wars of religion. Moreover, emerging patterns of exploration, contact, and mutual interaction among civilizations made freedom of communication a key issue in the early modern period. Scholars investigated the freedom of communication identifying what happened in the past and attempting to foresee what the future held, eventually transforming aspirations into political demands and legal claims, and conceptualizing mutual rights and obligations. On the one hand, international legal theorists investigated under which circumstances foreigners had the right to some form of hospitality. On the other hand, limits and constraints to migrations were identified 'through the enduring dialectic between sovereignty and hospitality'. ${ }^{147}$ In fact, the ius communicationis suffered from a major paradox: it could be both 'the founding principle of a universal society' and 'the main legal ground for justifying the colonial conquest of the New World.'148

Gentili assumed the existence of a right of communication; he had a cosmopolitan vision of the world, he saw the world as one city, and human beings as

\footnotetext{
142 Vincent Chetail, 'Sovereignty and Migration in the Doctrine of the Law of Nations: An Intellectual History of Hospitality from Vitoria to Vattel' (2017) 27 EJIL 901-922, 904.

143 Id. (citing Vitoria).

144 Id.

145 Id. 905 .

146 Cavallar, The Rights of Strangers, 10; James AR Nafziger, 'The General Admission of Aliens under International Law' (1983) 77 AJIL 804-847, 805-808.

147 Chetail, 'Sovereignty and Migration', 901.

148 Id. 905.
} 
its citizens; and he believed in the unity and sociability of human beings. ${ }^{149}$ Aware of the ambiguities and contradictions of the right of communication, Gentili did not conceive of the ius communicationis as an absolute right; rather, he envisaged some limits to its main articulations, the freedom of movement (ius peregrinandi) and the freedom of commerce (ius commercii). ${ }^{150}$

\subsubsection{The Freedom of Movement}

Under the law of nations, Gentili claimed that human beings also possessed the right to travel and dwell in foreign countries or freedom of movement (ius peregrinandi) provided that they did not harm foreign communities. ${ }^{151}$ For Gentili, as for Vitoria, the right to travel was a natural right that belonged to all: as citizens of the world, human beings could travel from one province to another. ${ }^{152}$ Gentili postulated international hospitality (hospitalitas) as one special form of interaction among individuals of different societies, political communities, and cultures. Analogously, Vitoria considered it 'humane and dutiful to behave hospitably to strangers' 153 and considered amity (amicitia) between human beings as 'part of natural law'.154 While Vitoria postulated the free movement of persons 'as a rule of international law' and an expression of 'the right of communication between people' (ius communicationis), ${ }^{155}$ and argued that 'the barbarians would do wrong to the Spaniards if they were to bar them from their lands, ${ }^{\prime} 56$ Gentili sought to strike a balance between inclusion and exclusion, the individual freedom of movement and the public interest, thus qualifying the right to migrate (ius migrandi) to a significant extent.

Gentili theorized a right to migrate for those who were 'compelled to leave their country through some emergency and to seek another home.' ${ }^{157}$ He noted that 'entire peoples have deserted their native soil and gone to a different part of the world' 158 because of 'the destruction of their cities', 'pestilence, or frequent earthquakes' or other 'intolerable defects of an unfavourable location.. 159 He suggested that human beings should have 'pity for their kind' and should

\footnotetext{
149 Gentili, De Iure Belli, Book I, Chapter 1, p. 67.

150 Lacchè, 'Introduzione', 10.

151 See also Vitoria, 'On American Indians', q. 3. Art. 1, para. 1.

$15^{2}$ Annabel S. Brett, Changes of State: Nature and the Limits of the City in Early Modern Natural Law (Princeton: Princeton University Press 2011) 29 (referring to Vitoria).

153 Vitoria, 'On American Indians', q. 3. Art. 1, para. 2.

154 Id.

155 Chetail, 'Sovereignty and Migration', 901 and 903.

156 Vitoria, 'On American Indians', q. 3. Art. 1, para. 2.

157 Gentili, De Iure Belli, Book I, Chapter 17, p. 79.

158 Id.

159 Id.
} 
not allow their demise. ${ }^{160}$ Therefore, for Gentili, people should be entitled to leave their own country in order to escape extreme evils such as earthquakes, civil strife, war, and religious persecution. Relying on the Roman poet Virgil, Gentili stated that 'it is just that those who have been driven from their own home should somehow find a safe place somewhere.'161

At the same time, Gentili sensibly qualified freedom of movement. The right of free movement was restricted to those who moved because of an emergency; it did not extend to those who migrated for 'greed and avarice, combined with a fondness to change their abode' (libido atque avaritia et mutandae sedis amor) ${ }^{162}$ Gentili further qualified the freedom of movement stressing that a safe place 'ought to be granted, if it c[ould] be given without too much inconvenience.'163 For instance, vacant lands could be used for the purpose, and the sovereign of the host state would retain jurisdiction over those who took possession of such lands and improved them. ${ }^{164}$ In that scenario, Gentili posited, 'newcomers ought to do what [was] most just and submit to the rule of [the sovereign] of the land'. ${ }^{165}$ Nonetheless, 'those lands which [we]re not vacant ought not to be taken; as it [wa]s not right that one should neglect oneself through love for another'.166 Finally, the state of destination could deny hospitality for good reasons such as public safety and state security. While Gentili noted that it may be in the interest of the host state to welcome refugees as 'an increase of population is beneficial for purposes of greatness', he was careful to add that 'in some instances' exiles were not to be made subjects of the host state 'if their number [wa]s so great as to be perilous to the commonwealth'.167 In conclusion, Gentili qualified freedom of movement to a significant extent.

\subsubsection{The Freedom of Commerce}

The early modern period was characterized by intense cultural, political, military, and economic contact. International trade certainly intensified global contacts; individuals, companies, tribes, states, and empires competed and clashed but also cooperated with one another. ${ }^{168}$ By maintaining commercial

\footnotetext{
160 Gentili, De Iure Belli, Book I, Chapter 17, p. 80.

161 Id.

162 Id.

163 Id. (emphasis added).

164 Id. pp. 80-81.

165 Id. p. 81.

166 Id.

167 Id. p. 80.

168 Kumkum Chatterjee and Clement Hawes, 'Introduction', in Kumkum Chatterjee and Clement Hawes (eds) Europe Observed-Multiple Gazes in Early Modern Encounters (Lewisburg: Bucknell University Press 2008) 1-19, 17.
} 
relations across religious and cultural boundaries, merchants performed an 'important function as commercial and cultural mediators' as commercial exchanges complemented if not fostered cultural exchanges. ${ }^{169}$ In other words, not only did religious and cultural diversity not prevent exchange, but trade enabled cultural flows stemming from multiple centres. Common ideas of fairness, reciprocity, and trust worked across cultural communities creating a space of cultural hybridity.

Gentili viewed commerce as a fact of nature and an expression of human sociability. ${ }^{170}$ To him, commerce is inherent to the design of nature because nations are naturally interdependent. Nature has distributed commodities over different regions 'in order that it may be necessary for human beings to have commerce with one another. ${ }^{171}$ Gentili elaborated the notion of comparative advantage: ' $[\mathrm{h}]$ ere the crops of grain are richest, there grapes grow best'.172 For Gentili, 'No blessing has been bestowed by divine providence upon any one for his sole enjoyment. But if nature had given everything equally to all men, the reasons for loving one another would readily be destroyed; for it is through this inequality that we ask and give in turn without ceasing. ${ }^{173}$ Through commerce, people enjoy the benefits of nature. Commercial activities do not merely benefit merchants; rather, they can benefit the community as a whole by addressing given needs. ${ }^{174}$ By divine design, ' $[\mathrm{e}]$ ach nation c[an] acquire what it lack[s] by supplying another nation with those gifts of which it had been given an abundance. ${ }^{175}$ Such interdependence requires people to enter into relationship with one another in order to thrive. Through commerce, all can enjoy the fruits of the earth, no matter where they grow. Moreover, not only is commerce necessary for the universal enjoyment of natural resources, but also

169 Francesca Trivellato, 'Introduction', in Francesca Trivellato, Leor Halevi, and Catia Antunes (eds) Religion and Trade: Cross-Cultural Exchanges in World History 1000-1900 (Oxford: OUP 2014) 1-3 (noting how, against the odds, merchants across the globe 'concocted ways of bartering, securing credit, and establishing durable commercial relations with people who did not speak their language, wore different garb, and worshipped other gods')

170 Ileana Porras, 'Appropriating Nature: Commerce, Property, and the Commodification of Nature in the Law of Nations' (2014) 27 Leiden JIL 641-66o, 651.

171 Gentili, DIB, Book I, Chapter 19, p. 88.

172 Id.

173 Id.

174 Ileana Porras, 'Constructing International Law in the East Indian Seas: Property, Sovereignty, Commerce and War in Hugo Grotius' De Iure Praedae - The Law of Prize and Booty, or on How to Distinguish Merchants from Pirates' (2005-2006) 31 Brooklyn JIL 741-804, 760 (referring to Grotius).

175 Id. 762 . 
for bringing peoples together. Therefore, commerce constitutes 'an instrument of providence' whereby products can be made available in places where they do not exist or at a time when they are not otherwise available. ${ }^{176}$

Gentili endorsed the doctrine of the providential function of commerce. ${ }^{177}$ Whereas medieval theological sources did not always view commerce in a positive light, ${ }^{178}$ Gentili saw trade as having not only an economic function but also as being instrumental to peace and prosperity. ${ }^{179}$ Because peoples need one another, 'their interchange makes the completeness of the universe.'180 Merchants 'serve the welfare of [hu]mankind'. ${ }^{181}$ In fact, by traversing the oceans, they ended the historical separation between different civilizations and could build peaceful and prosperous relations among nations. ${ }^{182}$ As Gentili wrote, 'It is an advantage to the earth that men sail at sea; to the sea that men journey over the earth ... The winds ... unite [peoples] separated in location. This is a wonderful gift of nature provided man's frenzy does not turn it to his own injury'183 Ahead of his time, Gentili approved inter-confessional trade relations. ${ }^{184}$

While Gentili considered freedom of trade to be a natural right, ${ }^{185}$ he also affirmed the state's right to regulate trade and investments and even to limit access to certain parts of their territories for security reasons under natural law and the law of nations. ${ }^{186}$ If free trade is a fair interest (ius commerciorum aequum est), public safety or state security (tuitio salutis) is a paramount interest. ${ }^{187}$ In fact, Gentili acknowledged that in some cases, trade can clash with the public interest, and that traders cannot 'set themselves as authorities on justice'. 188 While economic interests concern citizens and belong to private law

${ }_{17} 6$ Martti Koskenniemi, 'Vox Theologi: Empire and Private Rights in the 16th Century', in vVAA, Alberico Gentili-Giustizia, Guerra, Impero (Milan: Giuffrè 2014) 125-149', 136.

177 Ileana Porras, 'The Doctrine of the Providential Function of Commerce in International Law-Idealizing Trade', in Martti Koskenniemi, Mónica García-Salmones Rovira, and Paolo Amorosa (eds) International Law and Religion (Oxford: OU P 2017) 313-333, 313.

178 Porras, 'Constructing International Law in the East Indian Seas', 761.

179 Id.

18o Gentili, De Iure Belli, Book I, Chapter 19, p. 89 .

181 Porras, 'Constructing International Law in the East Indian Seas', 803.

182 Id. 763 .

183 Gentili, De Iure Belli, Book I, Chapter 19, pp. 88-89.

184 Id. Book III, Chapter 19; Gentili, Advocatio Hispanica Book I, Chapter 25, p. 117 (referring to 'the very definite rule of the law of nations which regulate[s] trade relations without making any distinction between nations').

185 Vitoria, 'On American Indians', q. 3. Art. 1, para. 3.

186 Pirillo, Filosofia ed Eresia nell'Inghilterra del Tardo Cinquecento, 183.

187 Gentili, De Iure Belli, Book I, Chapter 21, pp. 101-102.

188 Id. Book I, Chapter 3, p. 18. 
(ius privatorum), public safety concerns kingdoms and belongs to public law (ius regnorum). ${ }^{189}$ As Gentili put it, "let trade ... give way to sovereignty, man to nature, money to life.' 190 In fact, 'it is contrary to nature and contrary to the law of nations for private individuals to seek their own advantage at the expense of others.' ${ }^{191}$ Therefore, in case of conflict, priority must be given to the protection of life, public safety, and the reason of state (ratio status). ${ }^{192}$ Commerce must give way to the fundamental needs of the state (cedat regno mercatura). ${ }^{193}$ States can forbid the importation of harmful goods or commodities that are contrary to the religion or public morals of the country. ${ }^{194}$ For Gentili, 'strangers have no right to argue about these matters, since they have no license to alter the customs and institutions of foreign peoples.'195 Gentili highlighted that it is lawful to diminish the advantages of private individuals, provided some great gain is won for human society' ${ }^{\prime 96}$ For Gentili, conflicts of law could be settled by giving precedence to norms protecting the common good. For instance, he noted that China limited trade with European merchants to a series of Chinese ports, and he saw this practice as perfectly legitimate. ${ }^{197} \mathrm{He}$ explained, pragmatically, that 'a guest is not said to be rejected when he is not admitted to every part of a house. It is lawful to keep the secrets of a Kingdom concealed.' 198

Gentili attempted to strike a reasonable balance between national and international interests as well as private and public interests. On the one hand, while he supported the freedom of international commerce, he acknowledged that coastal states had the right to regulate and might adopt reasonable measures to restrict trade through their ports and passage through their coastal waters. ${ }^{199}$ For instance, states could legitimately adopt barriers to trade, such as banning exports in silver and gold to avoid the impoverishment of a given territory, provided that other forms of trade were maintained. ${ }^{200}$

189 Gentili, De Iure Belli, Book I, Chapter 3, p. 18.

190 Id.

191 Id.

192 Panizza, 'The Freedom of the Sea and the Modern Cosmopolis', 95.

193 Id.

194 Gentili, De Iure Belli, Book I, Chapter 19, pp. 89-90.

195 Id. p. 90.

196 Id. Book I, Chapter 21 p. 102.

197 Id. Book I, Chapter 19, p. 90.

198 Id.

199 Id. Book I, Chapter 21.

200 Id. Book I, Chapter 19, p. 9o. Cfr. Manuel Fraga Iribarne, Luis de Molina y el Derecho de la Guerra (Madrid: 1947) 66 (noting that the philosopher and theologian Luis de Molina (1535-160o) also admitted that states could legitimately set embargos, prohibit commerce 
On the other hand, Gentili also argued that the economic interests of merchants should not prevail over the public interest under both national and international law. ${ }^{201}$ For instance, he acknowledged the state's right to regulate and to prohibit trade in goods that might offend the religious tenets, cultural customs, or family values of the country. ${ }^{202} \mathrm{He}$ even recommended the extraterritorial application of national regulation prohibiting trade in certain goods 'as a matter of international comity'. ${ }^{203}$ In striking a balance between the reason of state and the needs of the wider human society, Gentili used 'a pragmatic spirit of moderation (moderatio). ${ }^{204} \mathrm{He}$ found a middle way between the static need of self-preservation and the dynamic need of international trade. ${ }^{205}$

Because Gentili considered freedom of the sea, freedom of communication, freedom of movement, and freedom of commerce as natural rights, he deemed unreasonable interference with such rights a significant injury, a wound on human society, and a justification for war. ${ }^{206}$ For Gentili, the total prohibition of passage, communication, and commerce between peoples without reasonable cause constituted a violation of the law of nations. ${ }^{207} \mathrm{In}$ fact, he argued that 'the unjustifiable refusal of passage' or harbour facilities amounted to a breach of the law of nations and could justify war. ${ }^{208}$ An unjustifiable interference with commerce constituted good cause for just war. ${ }^{209}$ If a sovereign 'refuse[d] the sea to others', those who '[we]re refused a privilege of nature' would 'be justified in making war'.210 While private individuals could defend their natural rights before domestic judges, Gentili noted that there were no

with foreigners, and block access to their own ports, if other nations did not face a state of necessity such as famine, thus necessarily needing to trade with the state, or if foreigners looked too powerful or aggressive. In fact, Molina argued, nations might have a just fear to be overcome or suffer any injury and thus they could prudently and legitimately adopt trade restrictions.)

201 Gentili, De Iure Belli, Book I, Chapters 1, 19, and 21; Book III, Chapters 11 and 19.

202 Id. Book I, Chapter 19, pp. 89-9o.

203 Simmonds, 'Alberico Gentili at the Admiralty Bar', 8; Gentili, Advocatio Hispanica, Book I, Chapter 13 .

204 Panizza, 'The Freedom of the Sea and the Modern Cosmopolis', 96.

205 Amor Bavaj, Alberico Gentili-Fondatore della Scienza del Diritto Internazionale (Macerata: Affede 1935) 57.

206 Gentili, De Iure Belli, Book I, Chapter 19, p. 88; Vitoria, 'On American Indians', q. 3. Art. 1, para. 6 .

207 See generally Gentili, De Iure Belli, Book I, Chapter 19, entitled 'On Natural Reasons for Making War'.

208 Gentili, De Iure Belli, Book I, Chapter 19, p. 87.

209 Id. p. 90.

210 Id. p. 92. 
international courts or tribunals for settling international disputes; therefore, if diplomatic means of dispute settlement failed, states would have no other means to defend their rights than to resort to war. ${ }^{211}$

Was Alberico Gentili advocating conquest? At the end of the sixteenth century and the beginning of the seventeenth century, the violent wars among Europeans and the intercivilizational encounters between merchants and the local inhabitants of other continents presented legal theorists with new questions about how to govern the interactions between different civilizations, whether to protect refugees, and if so how, how to govern international trade, how to balance the eventual clash between private and public interests, and between the interests of states and those of the international community. International law's trajectory reflected the key role of communication, trade, and movement in international relations from its earliest inception.

The cosmopolitan ideal 'of creating, preserving, and sustaining a global society of [hu]mankind could be used in principle to justify an extensive intervention in the affairs of other states or communities' and 'it could and did provide the basis of arguments that could be and were wielded to legitimize the colonial expansion of Europe.212 Historians have highlighted how commerce and migration were significant factors that contributed to the formation and expansion of early modern empires. ${ }^{213}$ For Gentili, navigation, communication, trade, and movement were all expressions of human nature, and should be left as free as possible. If international disputes arose because of the alleged violation of natural rights, states could resort to diplomatic means of dispute settlement; if these failed, states could resort to war. Yet, justifying war to promote free trade could lead to the so-called 'empire of commerce,, ${ }^{214}$ and ultimately justify violence on behalf of trade. ${ }^{215}$

However, there are anti-imperialist arguments in the Gentilian theory as well. Gentili was aware of the possible instrumentalization of the law of nations

\footnotetext{
211 Gentili, De Iure Belli, Book I, Chapter 19, p. 92.

212 Panizza, 'The Freedom of the Sea and the Modern Cosmopolis', 94.

213 Alison Games, Migration and the Origins of the English Atlantic World (Cambridge: Harvard University Press 1999); Alison Games, Web of Empire: English Cosmopolitans in an Age of Expansion 1560-166o (New York: OUP 2008); Lauren A. Benton, A Search for Sovereignty: Law and Geography in European Empires 1400-1900 (New York: CUP 2010).

214 Diego Panizza, 'Languages of Empire in Early Modern Political Theory: from Machiavelli's Roman Paradigm to the Modern Empire of Commerce', in vVAA, Alberico GentiliGiustizia, Guerra, Impero (Milan: Giuffrè 2014) 349-390, 353.

215 Porras, 'Constructing International Law in the East Indian Seas', 756.
} 
and understood that, in some cases, trade could be used as a means of disguising conquest. Therefore, he denied the legitimacy of the Spanish wars against Indigenous peoples on the ground that the Indians allegedly denied the Spaniards the possibility to trade with them. Whereas denial of commerce could be a legitimate cause of war in theory, it could not justify the Spanish war against Indigenous peoples in practice, because 'the Spaniards were aiming ... not at commerce, but at dominion'. ${ }^{216}$ Therefore, Gentili argued that the Spanish wars against Indigenous peoples could not be considered lawful. With regard to migrations, Gentili forcefully affirmed that 'it [was] not just ... that the weaker ... should give place to the more powerful' and rejected that the law of might could be the law of right. ${ }^{217}$ Moreover, he did not necessarily prioritize international interests over domestic ones. His theory carefully balanced private and public interests and also domestic and international interests by stressing the importance of public safety, state security, and other legitimate concerns. Finally, not only did Gentili openly condemn policies of empire, but he also rejected the argument of terra nullius. He acknowledged the sovereignty and property rights of Indigenous peoples and considered the occupation of vacant lands as a tool to acquire property, rather than sovereignty, over those lands. ${ }^{218}$

In conclusion, if some of Gentili's arguments can be read as supporting some form of imperialism, others have a distinct anti-hegemonic character. Whereas for some scholars Gentili was a firm supporter of imperialism, for others he was not. Both interpretations seem plausible given that they are based on distinct aspects of Gentili's work. However, adopting a holistic approach to his work reveals that Gentili's theory unquestionably clashed with expansionist ambitions. The general neglect of Gentili's work after his death may reflect the fact that his anti-imperialist stances were difficult to reconcile with the imperial policies pursued by major maritime powers in the seventeenth and eighteenth centuries. However, the aim of this book is not to persuade the reader in one direction or the other, but rather to provide the tools for a better understanding of the man and his work. The reader can decide if Gentili supported conquest or not. Before addressing this topic in more detail in chapter 7, the chapter now examines Gentili's theory on piracy and privateering.

216 Gentili, De Iure Belli, Book I, Chapter 19, p. 89.

217 Id. Book I, Chapter 17, p. 8 o.

218 See Chapter 7 below. 


\subsection{Piracy and Privateering}

In the sixteenth century, private maritime violence, 'as old as maritime trade itself, developed into a global phenomenon'. ${ }^{219}$ Whether sea robbers were 'disrupters to networks of economic and cultural exchange', key economic and political actors ${ }^{220}$ or even a defining feature of the early modern international law of the sea ${ }^{221}$ remains contested. The treatment of private maritime violence under the law of nations oscillated between condemnation and instrumentalization, and there was a significant divergence between international legal theory and state practice. ${ }^{22}$ Such ambivalence was reflected in the distinction between piracy and privateering.

Piracy broadly referred to acts of violence, detention or depredation by private actors upon a ship or a coastal area, typically with the goal of stealing cargo and other valuable items. ${ }^{223}$ Acts of piracy at land or at sea were rarely distinguished. ${ }^{224}$ Gentili defined piracy as 'any taking not authorized by a sovereign' and pirates (piratae) as 'the enemies of all' (communes hostes omnium). ${ }^{225}$ Relying on the civilian tradition, for Gentili, pirates could be 'attacked by all ... with impunity' and were 'always subject to capture everywhere., ${ }^{26}$ While Gentili generally argued for moderation in the conduct

219 Kempe, 'Globalized Piracy and International Law', 354.

220 Claire Jowitt, 'Introduction: Pirates? The Politics of Plunder, 1550-1650', in Claire Jowitt (ed.) Pirates? The Politics of Plunder, 1550-1650 (New York: Palgrave 2007) 3-19, 3.

221 Gerry Simpson, 'Piracy and the Origins of Enmity', in Matthew Craven, Malgosia Fitzmaurice, and Maria Vogiatzi (eds.) Time, History, and International Law (Leiden: Brill 2007) 219, 223.

222 Kempe, 'Globalized Piracy and International Law', 354.

223 For the current definition of piracy under contemporary international law, see Convention on the High Seas, signed on 29 April 1958, in force 30 September 1962, UNTS 450, Article 15 (defining piracy, inter alia, as '[a]ny illegal acts of violence, detention or any act of depredation, committed for private ends by the crew or the passengers of a private ship ... and directed on the high seas, against another ship ... or against persons or property on board such ship.); UNCLOS Article 101 (repeating almost verbatim Article 15 of the Convention on the High Seas). See also Rome Convention for the Suppression of Unlawful Acts against the Safety of Maritime Navigation, adopted 10 March 1988, in force 1 March 1992, 1678 UNTS 221.

224 Mark Chadwick, Piracy and the Origins of Universal Jurisdiction (Leiden/Boston: Brill 2019) 72 .

225 Lauren Benton, 'Legal Spaces of Empire: Piracy and the Origins of Ocean Regionalism' (2005) 47 Comparative Studies in Society and History 700-724, 705.

226 Gentili, Hispanica Advocatio, Book I, Chapter 4, p. 18; Pierino Belli, De Re Militari et Bello Tractatus [1563] Herbert Nutting (transl.) (Oxford: Clarendon 1933) 83 (claiming that 'pirates [were] wholly outside the pale of law' so that 'it should be permissible for anyone to attack them') 
of war, he supported the harsh treatment of pirates. For Gentili pirates did not qualify as 'just enemies' (iusti hostes); rather, they were outside the law, and were thus not protected by the law of nations. ${ }^{227}$ By juxtaposing piracy and warfare as two distinct and mutually exclusive categories, Gentili not only reduced pirates to inhuman predators driven by nothing but greed, but also elevated states to a higher plane that obscured instances in which states behaved inhumanly. The characterization of pirates as enemies of humankind delegitimized them as unjust enemies, portrayed them as outliers, as chimerical 'others' who threatened to undermine the international system, and ultimately justified brutal military repression. ${ }^{228}$ While most states formally condemned piracy, they 'repeatedly adjusted' the legal concept of piracy to suit their economic or political ambitions. ${ }^{229}$

Privateering referred to 'state-sponsored maritime raiding. ${ }^{230}$ It was 'a form of maritime plunder carried out by private parties but authorized and sponsored by state authority through formal documentation. ${ }^{231}$ States could authorize corsairs or privateers to conduct raids on the ships of a foreign nation in times of war and in times of peace. In times of war, privateering amounted to a form of naval warfare. Corsairs served as a sort of auxiliary navy 'at a time when warships were few and far between'.232 In times of peace, privateering was a form of reprisal to avenge a perceived breach of the law of nations by a foreign state. ${ }^{233}$ In practice, privateers were often 'pirates in all but name'. ${ }^{234}$ Their aims, methods, and conduct were similar to those of pirates, albeit under the mantle of state authorization. Privateers sought and received letters of marque and reprisal authorizing them to attack and capture enemy ships. ${ }^{235}$

227 Gentili, De Iure Belli, Book II, Chapter 24, p. 283 (adding that 'pirates, when taken m[ight] be punished by shameful death ... and left unburied'); Marcus Rediker, Villains of All Nations: Atlantic Pirates in the Golden Age (Boston: Beacon Press 2004).

228 Peter Schröder, 'Vitoria, Gentili, Bodin: Sovereignty and the Law of Nations' in Benedict Kingsbury and Benjamin Straumann (eds) The Roman Foundations of the Law of Nations (Oxford: OUP 2010) 163, 178.

229 Kempe, 'Globalized Piracy and International Law', 354.

230 Lauren Benton, 'Toward a New Legal History of Piracy: Maritime Legalities and the Myth of Universal Jurisdiction' (2011) 23 International Journal of Maritime History 225-240, 230.

231 Christopher Harding, 'Hostis Humani Generis - The Pirate as Outlaw in the Early Modern Law of the Sea' in Claire Jowitt (ed.) Pirates? The Politics of Plunder, 1550-1650 (New York: Palgrave 2007) 20-38, 24.

232 Porras, 'Constructing International Law in the East Indian Seas', $75^{2-753 . ~}$

233 Tullio Scovazzi, 'Alberico Gentili e il Diritto del Mare', in Talitha Vassalli di Dachenhausen (ed.) Atti del Convegno in Memoria di Luigi Sico (Napoli: Editoriale Scientifica 2011) 489497,495 .

234 Simmonds, 'Alberico Gentili at the Admiralty Bar', 10.

235 Benton, 'Toward a New Legal History of Piracy', 230. 
According to maritime practice, privateers then brought their 'prizes' before the Admiralty Court, which adjudicated title. ${ }^{236}$ If the Court found that the ship, cargo or both was a lawful prize, the spoils were carefully divided between the Admiralty and the privateer. If the court found that the prize was not a lawful prize, it ruled in favour of the original owner.

While piracy tended to be universally condemned as a crime, subject to universal jurisdiction - that is, the right of any polity to capture, try, and punish offenders - the legitimacy of privateering was vigorously debated.237 The question was whether war-like activities by non-state actors could be legitimized in this manner. While, in theory, there was a clear difference between privateers and pirates, in practice, 'the line between privateering and piracy was thin, and the distinction was blurred by cycles of ... war and peace: In times of war, the demand for privateers surged, and in periods of peace, decommissioned, experienced sea raiders found themselves without sponsors yet sometimes continued to engage in raiding. 238

Whether certain crews were considered pirates or privateers often depended on whose custody they found themselves in - that of the country that had issued the commission, or that of the object of attack. As noted by a historian, ' $[t]$ he boundary between licit and illicit activity at sea in this period [was] permeable: one monarch's 'pirate' [was], literally, another's 'privateer'.239 Certain countries, including Spain, questioned whether privateers could legitimately wage war and contested the existence of any dividing line between privateers and pirates. ${ }^{240}$ From the Spanish perspective, the Lutheran corsairs (corsarios luteranos) - the Huguenot buccaneers, the Dutch freebooters, and the Elizabethan Sea Dogs, all privateers commissioned by Protestant sovereigns who crossed the papal lines of demarcation, preyed on the Spanish colonies, and assaulted the Spanish galleons - were both pirates and 'excommunicated heretics', thus challenging 'not only Spanish interests but also the unity of the

236 Alfred Rubin, 'The Concept of Neutrality in International Law' (1988) 16 Denver JIL and Policy 361 .

237 Jan Lemnitzer, Power, Law, and the End of Privateering (Basingstoke: Palgrave Macmillan 2014) (explaining that only in the nineteenth century did the Declaration of Paris outlaw privateering.); Declaration respecting Maritime Law between Austria, France, Great Britain, Prussia, Russia, Sardinia, and Turkey, signed at Paris, 16 April 1856 (1856) XLVI British and Foreign State Papers, p. 26, Article 1 (stating that 'Privateering is, and remains, abolished').

238 Benton, 'Legal Spaces of Empire', 707.

239 Jowitt, 'Introduction: Pirates?' 13.

240 C.G. Roelofsen, 'Grotius and State Practice of His Day' (1989) 10 Grotiana 18. 
Christian commonwealth' and the imperial order. ${ }^{241}$ The punishment of such 'pirates' was to be handed over to the Inquisition where they were tried for heresy. Furthermore, privateers could be charged with piracy if they exceeded the bounds of their letters of marque, for instance by attacking neutral nations, or failing to bring their prize before admiralty courts. ${ }^{242}$ Therefore, " $[\mathrm{t}]$ he legality of their actions depended upon open and conflicting interpretations of whether the timing, location, and targets of raids fell within the terms of often dubious commissions. ${ }^{243}$

An example, drawn from Gentili's practice as an advocate defending the interests of Spain before the High Court of Admiralty, can illustrate the difficulty in distinguishing privateering from piracy in practice. ${ }^{244}$ In Botelho c. Hendrik de Jong, a Portuguese merchant sued a Dutch privateer/pirate before the High Court of Admiralty requiring the restitution of a ship, the San Antonio, and its cargo. $^{245}$ On Christmas Day 1604, while the San Antonio was sailing from Lisbon to Brazil, the Vineyard, a warship under the command of de Jong attacked it and took it as a prize. ${ }^{246}$ De Jong had a letter of marque from the United Provinces, which were then at war with Spain and thus also with Portugal (given the union of the Crown of Portugal and the Crown of Spain in 1580). ${ }^{247}$ While en route to Holland, a storm forced him to seek shelter in an English port. ${ }^{248}$ Once there, the English vice-admiral seized his booty on the ground that de Jong had committed 'hostile and warlike acts within English territory'. ${ }^{249}$ In London, joined by the Ambassador of the King of Spain, Botelho, the owner of the ship, sued de Jong before the High Court of Admiralty in order to recover his property. 250

For Thomas Crompton, the advocate defending the interests of de Jong, the privateers had acquired the San Antonio as a lawful prize. ${ }^{251}$ In fact, military

\footnotetext{
241 Amedeo Policante, The Pirate Myth (London: Routledge 2015) xviii.

242 Benton, 'Toward a New Legal History of Piracy', 231.

243 Benton, 'Legal Spaces of Empire', 707.

244 Gentili, Hispanica Advocatio, Book I, Chapter X, pp. 47-49.

245 Wijffels, 'Alberico Gentili and Thomas Crompton' (referring to the Caesar's Papers. Botelho c. Hendrik de Jong, Lansdowne 131, ff 270v-294r, Lansdowne 132, ff. 53v-56r, Lansdowne $139 \mathrm{ff}$ 112r-128v.)

246 Id. 9 .

247 Id.

248 Simmonds, 'Alberico Gentili at the Admiralty Bar', 13.

249 Id.

$25^{\circ}$ Wijffels, 'Alberico Gentili and Thomas Crompton', 9.

251 Alain Wijffels, 'Alberico Gentili e Thomas Crompton. Una Sfida tra un Professore e un Avvocato', in Alain Wijffels (ed.) Alberico Gentili Consiliatore (Milan: Giuffrè 1999) 25-83, 69 .
} 
practice regarded a seizure as final when it had been held for a short time. Therefore, for Crompton, the Court should recognize and protect de Jong's exercise of his rights and let him depart with the ship and its cargo. ${ }^{252}$ For the Spanish Ambassador, 'a judgment against the Portuguese merchants would effectively defeat the guarantees provided in the [1604] peace treaty' between England and Spain. ${ }^{253}$ In such treaty, England adopted a position of neutrality with regard to the war between Spain and the United Provinces. ${ }^{254}$ Concerning the nationality of the warship, the Ambassador produced evidence that 'de Jong was the only Dutchman onboard' the Vineyard, the ship that captured the San Antonio. ${ }^{255}$ Forty-five men out of the crew of fifty were English. ${ }^{256}$ The same Vineyard had originally set forth from an English port. ${ }^{257}$ Reportedly, 'English merchants had provided all the funds for acquiring and furnishing the ship'.258

In his pleading, Gentili argued that the privateers had not yet acquired the San Antonio as a lawful prize. ${ }^{259}$ Following Baldus, Alciatus, and Ayala, in opposition to the military practice cited by his opponent, Gentili pointed out that from a legal perspective, a prize only became the property of the captors when they carried their booty within their own fortified lines, in this case the United Provinces. ${ }^{260}$ The orthodox position in prize law was that the acquisition of a prize required a formal adjudication. Therefore, for Gentili, 'the Dutch had not acquired a legal title to the property', because the ship 'had not been brought within their own fortified lines'261 and the Court should allow the return of the property to its original owners. ${ }^{262}$ Finally, Gentili recalled that King James I had condemned privateering as a form of plunder and forbade any hostile action against the Spaniards. ${ }^{263}$ Gentili elegantly concluded that because almost everyone onboard the ship was British, the ship was piratical; therefore, the booty should be restored to the original owners. ${ }^{264}$

\footnotetext{
252 Wijffels, 'Alberico Gentili e Thomas Crompton', 69-70.

253 Wijffels, 'Alberico Gentili and Thomas Crompton', 9.

254 Simmonds, 'Alberico Gentili at the Admiralty Bar', 5 .

255 Wijffels, 'Alberico Gentili and Thomas Crompton', 9.

256 Id.

257 Id.

258 Id.

259 Gentili, Hispanica Advocatio, Book I, Chapter X, p. 48.

26 Id. Book I, Chapter II, p. 7.

261 Id. Book I, Chapter II, p. 48.

262 Id. Book I, Chapter X, p. 48.

263 Id. Book I, Chapter XVI, p. 73.

264 Id. Book I, Chapter X, pp. 48 and 73.
} 
The Court of Admiralty rendered a decision in favour of the Portuguese merchants who recovered the ship and its cargo. ${ }^{265}$ In the adjudication of this admiralty dispute, policy considerations mattered. In fact, 'an undated and unsigned memorandum, written in Italian', conserved among the Caesar papers, cautioned that if the Court did not adjudicate in favour of the Portuguese merchants, similar predations would rapidly increase in number. ${ }^{266}$ In turn, such violations of the peace treaty provisions could eventually lead to a new war. This case study epitomizes the difficulty in distinguishing privateering from piracy in practice. It also shows how legal and policy arguments were intertwined in the early modern law of the sea.

Certainly, the legal notions of piracy and privateering 'did not develop in isolation but responded directly to shifting patterns of violence at sea. ${ }^{267}$ The boundary betweenlegitimate andillegitimate violenceatsea was'permeable,268 and deeply connected to the foreign policy of states in relation to warfare and commerce. States used privateering for political and economic reasons, not only to wage war, but also to challenge Iberian hegemony in the Americas and further their foreign mercantilist policies. ${ }^{269}$ In fact, privateering simultaneously provided 'an economic mode of warfare and a violent way of doing business'. 270 The regular issuing of letters of marque to authorize corsairs legally disguised the political and economic use by the state of violence at sea. ${ }^{271}$

The maritime policy of Elizabethan England included a varied practice, ranging from the self-defence of merchant vessels to various forms of reprisals, and from privateering to 'sheer bald piracy' ${ }^{272}$ 'Other nations did not always clearly distinguish' the various motives behind an attack against their ships: some captures were alleged to prevent contraband; other seizures were alleged to constitute a legitimate reprisal, or privateering; finally, certain captures definitely had a piratical nature. ${ }^{273}$ 'The state papers, reports of ambassadors, and foreign correspondence are full of bitter complaints of English depredations at sea.'. ${ }^{274}$

265 Nys, 'Les Manuscripts de Sir Julius Caesar', 465.

266 Wijffels, 'Alberico Gentili and Thomas Crompton', 28.

267 Benton, 'Toward a New Legal History of Piracy', 225.

268 Jowitt, 'Introduction: Pirates?' 7; Claire Jowitt, The Culture of Piracy 1580-1630 (Farnham: Ashgate 2010) 8 (noting that 'the category of pirate included[d] a wide variety of figures from all sorts of social, religious, and ethnic backgrounds, who were variously defined in different cultural registers as "pirates", "corsairs", "buccaneers", and "filibusters"').

269 Kempe, 'Globalized Piracy and International Law', $35^{8}$.

270 Harding, 'Hostis Humani Generis', 26.

271 Id.

272 Cheney, 'International Law under Queen Elizabeth', 671.

273 Id.

274 Id. 672. 
Despite the condemnation of piracy and the uncertain legal status of privateering in the early modern period, privateering was used to great effect for both political and economic reasons. Since the 156os Elizabeth I had granted privateering commissions to Sir Francis Drake (1540-1596) and the Sea Dogsa group of sea-raiders - to attack the Spanish fleet and loot their galleons in order to bring back riches and treasure. ${ }^{275}$ During the Anglo-Spanish War (1585-1604), privateering became a means of waging war. ${ }^{276}$ Far from being 'an incidental by-product of war', it became 'the characteristic form of maritime warfare. ${ }^{277}$ Spain's hegemonic ambitions, both within and outside Europe, and its threat to invade the country required defensive action; privateering became both a way to wage war, and a tool of economic competition with other countries. ${ }^{278}$

On the one hand, privateering constituted 'a technique of warfare' at a time when most countries' navies were not equipped for large-scale or sustained military action. ${ }^{279}$ Recourse to privateering constituted a revolution in naval strategy, protecting coastal communities, strengthening the fleet, and ultimately becoming part of a military policy. Due to English anxieties about the strength of the Navy in relation to other sea-powers ${ }^{280}$ and the lack of funds to expand the fleet, privateering became a 'joint venture between state and private entrepreneurs - a kind of privatization of state warfare.' ${ }^{281}$

On the other hand, privateering was also a tool of economic competition with other countries. Privateers jeopardized the maritime trade of an enemy state by attacking its merchant shipping. ${ }^{282}$ In the end, the military and economic benefits provided by privateers seemed to outweigh the diplomatic inconveniences caused by any piratical behaviour of the same. Privateers played an important role in defending the country from attacks by sea, opened up new markets, and disrupted the Spanish hegemony in the Americas. ${ }^{283}$

\footnotetext{
275 Chadwick, Piracy and the Origins of Universal Jurisdiction, 59.

276 Philip Gosse, The History of Piracy (New York: Tudor 1934) 113.

277 Kenneth R. Andrews, Elizabethan Privateering (Cambridge: CUP 1964) 6.

278 Jowitt, 'Introduction: Pirates?' 4.

279 Harding, 'Hostis Humani Generis', 24.

280 Jowitt, 'Introduction: Pirates?', 11.

281 Harding, 'Hostis Humani Generis', 25.

282 Id. 24-25.

283 Anne Pérotin Dumon 'The Pirate and the Emperor: Power and Law on the Seas 1450-1850', in James D. Tracy (ed) The Political Economy of Merchant Empires State Power and World Trade, 1350-1750 (Cambridge: CUP 1991) 196-227, reprinted in C.R Pennel (ed.) Bandits at Sea: A Pirates Reader (New York: NYU Press 2001) 25-55, 33-33.
} 
Privateers thus played a number of roles: 'as agents of warfare; agents of commerce; [and] agents of exploration'. ${ }^{284}$

After the death of Queen Elizabeth in 1603, her successor James I sought to end the Anglo-Spanish War. Under the Treaty of London, signed on 18 August 1604, Spain formally recognised the Protestant monarchy in England, while England ended its financial and military support for the Dutch rebellion, assuming neutral status in the ongoing war between Spain and the Dutch Provinces. The Treaty opened the English Channel to Spanish shipping and required the end of any trade disruption at sea. Accordingly, James I took 'measures against piracy' and 'forb[ade] all ... assistance to privateers who attacked ships of friendly nations.' ${ }^{285}$ International trade became a prime objective of the nascent British empire.

Alberico Gentili was the first to 'systematically ... develop a concept of piracy' in international legal theory, and his model remains current. ${ }^{286}$ Relying on Cicero's classical definition of pirates as anyone's common enemy (communis hostis omnium), Gentili endowed it 'with greater precision'; for Gentili, pirates represented the enemies of all humankind because they acted against the law of nations and the human society (contra ius gentium et contra humanae societatis communione). ${ }^{287} \mathrm{He}$ briefly mentioned an episode that Augustine narrated in De Civitate Dei (City of God) in which a captured pirate gave 'an apt and true reply' to Alexander the Great when asked why he kept 'hostile possession of the sea'. The pirate responded by asking the sovereign why he seized the whole earth. Thus, the pirate who ruled the sea with a mere ship was called a robber, and yet the king who ruled it with a great fleet was styled as an emperor. $^{288}$ Gentili concluded that both imperial expansion and piracy were unlawful under the law of nations.

From the conceptualization of pirates as universal enemies, Gentili derived a universal right to prosecute and punish pirates. ${ }^{289}$ For Gentili, pirates did not enjoy any rights under international law for they lost the protection of their home state. ${ }^{290}$ Because piracy was an international crime, all nations could wage war against pirates (bellum piraticum). ${ }^{291}$ As the common enemies of

\footnotetext{
284 Harding, 'Hostis Humani Generis', 27.

285 Wijffels, 'Alberico Gentili and Thomas Crompton', 11.

286 Kempe, 'Globalized Piracy and International Law', 356.

287 Gentili, De Iure Belli, Book 1, Chapter 25, p. 124.

288 Id. Book I, Chapter 4, p. 24 referring to Augustine, The City of God against the Pagans, R.W. Dyson (trans) (New York: CUP 1998) Book IV, Chapter IV.

289 Gentili, De Iure Belli, Book 1, Chapter 25, p. 124.

290 Id. Book I, Chapter 4, p. 24; Book III, Chapter 23, p. 423.

291 Id.
} 
humankind (hostis humani generis), they were subject to universal jurisdiction, could be brought to justice everywhere, ${ }^{292}$ and could be punished by all. ${ }^{293}$ Universal jurisdiction over piracy was certainly aimed at preventing a common danger and 'optimizing law enforcement', given that piracy often occurred outside any state's territorial jurisdiction. ${ }^{294}$ States regularly criminalized piracy as a capital offence, and suppressed foreign perpetrators when the home state was not prepared to act. ${ }^{295}$

While Gentili's position on piracy remained the same over the course of his career, his position on privateering changed considerably. During the Elizabethan reign, he considered privateering - that is, raiding with the authorization of a sovereign - a legitimate pursuit. Published during the Anglo-Spanish war, his De Iure Belli explicitly distinguished French privateers from pirates because they possessed and exhibited letters of their king. ${ }^{296}$ In times of war, Gentili considered privateers as 'naval allies' (socii navales). ${ }^{297}$ For Gentili, 'the assumption of a public cause' could transform privateers into allies; relying on Roman history, he referred to the most important leader of the Lusitanian people, Viriathus (180вС-139вс), who turned from private brigandage to the defence of his country, eventually becoming a general. ${ }^{298}$ Was Gentili implicitly referring to the Sea Dogs? The irony was that the Iberian Viriathus resisted Roman imperial expansion into the regions of western Spain; while Elizabethan privateers were resisting the Iberian Empire. To illustrate the point, and perhaps to make it more palatable to an international audience, Gentili also provided other examples from Palestine, Persia, and Asia. ${ }^{299}$

Gentili's stance on privateering changed considerably after James I adopted a tougher stance on piracy. ${ }^{300}$ At the domestic level, pirates were defined as enemies of all humankind (hostes humani generis) and the Chief Justice Edward Coke (1552-1634) even equated domestic pirates to traitors. ${ }^{301}$ Reflecting his government's change of policy, Gentili condemned privateering as a form

\footnotetext{
292 Harding, 'Hostis Humani Generis', 21.

293 Gentili, De Iure Belli, Book I, Chapter 4, p. 22; Book II, Chapter 14, p. 199; Book III, Chapter 23, p. 423.

294 Harding, 'Hostis Humani Generis', 23.

295 Chadwick, Piracy and the Origins of Universal Jurisdiction, 75.

296 Gentili, De Iure Belli, Book I, Chapter 4, p. 26.

297 Id. Book II, Chapter 14, p. 199.

298 Id. Book I, Chapter 4, pp. 24-25.

299 Id. p. 25.

300 Chadwick, Piracy and the Origins of Universal Jurisdiction, 73 (reporting that King James I of England considered pirates as 'enemies of God and Men'.)

301 Id. 77 (explaining that 'the equation of piracy with treason rested on the ancient feudal notion' that subjects were bound in loyalty to their sovereign.)
} 
of piracy. For Gentili, the granting of letters of marque amounted to a deliberate sanction of robbery of merchants. For instance, in the Advocatio Hispanica, when discussing booty captured under letters of marque by Dutch privateers from Spaniards, he denounced the Dutch as pirates, thus legitimizing the detention of the Dutch ship on the high seas by the Englishmen and its removal to England, considering this as an exercise of England's jurisdiction. ${ }^{302}$ Acting as an advocate for merchants whose goods had been seized in the Mediterranean Sea and then sold to English merchants in Barbary ports, he argued that the Barbary states were supporting pirates and that the sale was unlawful. ${ }^{303}$ For Gentili, if 'brigands $\mathrm{t}[\mathrm{ook}]$ a thing away, they $\mathrm{d}[\mathrm{id}]$ not take away its ownership'.304 Therefore, 'the right to stolen property [wa]s everlasting',305 and 'whoever b[ought] from [pirates] directly or indirectly $\mathrm{d}[\mathrm{id}]$ not acquire title in the goods, regardless of possible unawareness that the goods came from pirates' ${ }^{306}$ Therefore, he argued that English buyers, who bought goods in Tunis from pirates, should return the items to the Spaniards, the victims of the pirates. ${ }^{307}$

Yet, 'Gentili also argued the opposite direction' when the interests of his clients demanded it. ${ }^{308}$ In Venetian Merchants c. English Merchants of Barbary, ${ }^{309}$ Venetian merchants required the restitution of goods seized by the notorious English pirate John Ward, then based in Tunis. As mentioned, since the conclusion of the peace with Spain in 1604, James I reversed the Elizabethan policy of sponsoring privateering against Spain. In this context, English mariners such as Ward 'turned to the Mediterranean both to trade and to raid'.310 In April 1607, the Venetian ship Reniera e Soderina was carrying a cargo of cotton, cinnamon, indigo, and silk worth more than five hundred thousand crowns, when

\footnotetext{
302 Nussbaum, A Concise History of the Law of Nations, 99.

303 Benton, 'Toward a New Legal History of Piracy', 229.

304 Gentili, De Iure Belli, Book III, Chapter 23, p. 423.

305 Id. p. 424.

306 Nussbaum, A Concise History of the Law of Nations, 99.

307 Id.

308 Id.; White, Piracy and Law in the Ottoman Mediterranean, 178 (noting that Gentili 'struggled with whether the North African provinces, as [formally] constituent parts of the Ottoman Empire, exercised sovereignty or not, and thus whether they were covered by the content of the sultan's treaties. He argued both sides depending on his employer'); Gentili, Hispanica Advocatio, Book I, Chapter XXIII, pp. 108-109 ('my opponents will say that ... I am contradicting myself if I argue otherwise. But there are differences between the present case and that').

309 Wijffels, 'Sir Julius Caesar and the Merchants of Venice', (referring to Venetian Merchants c. English Merchants of Barbary, Lansdowne 145, ff. 167r, 285r-303v.)

310 Benton, 'Piracy and Politics in Gentili's Hispanica Advocatio', 175.
} 
Ward seized it near Cyprus. ${ }^{311}$ After the capture of the ship, Ward returned to Tunis and sold the booty to a local civil servant, Cara Osman (or Crosman), who was a captain of the Janissaries, elite infantry units that formed the Ottoman Sultan's troops. ${ }^{312}$ English merchants bought the cargo and brought it to London in October $1607{ }^{313}$ In November 1607, the Venetians sued the English merchants before the High Court of Admiralty, reclaiming the goods and obtaining the seizure of the same. ${ }^{314}$ The case became of object of intense political pressure.

On behalf of the Venetian merchants, the Venetian Ambassador claimed that Jack Ward was an infamous pirate and that Crosman did not exist and was an invented go-between. ${ }^{315}$ Even admitting the existence of Crosman and his role in the affair, the Ambassador argued that Venice and the Ottoman Empire, which included Tunis, were at peace, and therefore, Crosman should not have bought stolen goods. ${ }^{316}$ Although Venice and the Ottoman Empire had been at peace since 1573, the North African port cities that were formally a part of the Ottoman Empire hardly respected the treaty. ${ }^{317}$ The Ambassador implicitly hinted that the plunder of the Reniera e Soderina was a case of state piracy, as 'Ward might qualify as a regular privateer in the service of Tunis.' ${ }^{318}$ In fact, Ward depended 'on the local ruler's protection in order to secure for his ships and crew a safe basis' where he could 'sell the product of his enterprises', and 're-equip his fleet'. 319 In turn, Tunis 'secured a constant influx of goods', 'attracted foreign merchants, and thus enhanced [its] importance ... as a marketplace. ${ }^{320}$ Finally, the Ambassador also alleged the bad faith of the English buyers. ${ }^{321}$

On their part, the English merchants 'protested that ... their trade had always been honest' and that they bought their cargo in Tunis from the local authorities. ${ }^{322}$ As the Venetian merchants had obtained an expert opinion

311 Daniel J. Vitkus, 'Introduction', in Daniel J. Vitkus (ed.) Three Turk Plays from Early Modern England (New York: Columbia University Press 1999) 1-35, 25.

312 Nys, 'Les Manuscripts de Sir Julius Caesar', 466.

313 Id.

314 Id.

315 Id.

316 Id.

317 Joshua M. White, Piracy and Law in the Ottoman Mediterranean (Stanford, CA: Stanford University Press 2018) 4.

318 Wijffels, 'Sir Julius Caesar and the Merchants of Venice', 204.

319 Id. 202.

320 Id.

321 Simmonds, 'Alberico Gentili at the Admiralty Bar', 12.

322 Wijffels, 'Sir Julius Caesar and the Merchants of Venice', 198. 
(consilium) from a Professor of the University of Padua, the English merchants sought the advice of Alberico Gentili. ${ }^{323}$ In a memorial submitted to the Court, dated 5 June 1608 , Gentili stated that he did not intend to support piracy in any way, but he nonetheless argued that the English merchants had legitimate title to the goods. ${ }^{324}$ For Gentili, the sale was legitimate under Turkish law because it had the approval of Barbary officials and followed all the local formalities. ${ }^{325}$ Gentili also explained that because Venice had a peace treaty with the Ottoman Empire, the Venetians thus had the possibility to file claims in the place where the transaction occurred. ${ }^{326}$ They would need to prove that they had been subjected to a piratical attack. ${ }^{327}$ However, they would not be able to do so, because they had been attacked by privateers sponsored by the Ottomans themselves and this would be evidence of war between the Ottomans and Venice despite the peace treaty. 328

The reason of state and international justice prevailed over Gentili's argument. In fact, the Court of Admiralty rendered a decision in favour of the Venetian merchants. ${ }^{329}$ For Venice, 'the case had major implications for the safety of Venetian trade in the Mediterranean'. ${ }^{330}$ For England, friendly commercial relations with Venice were key to the success of the King's European peace policy and the promotion of English trade. ${ }^{331}$ Moreover, because 'Venice was a privileged observatory of Italian as well as international affairs', England sought to remain on good terms with Venice to also 'gather intelligence on international politics'. ${ }^{332}$ After consultation with the Venetian Doge, James I came to the conclusion that he would never pardon Ward without the assent of the Republic of Venice; while the Republic expected that no pardon would be granted until full indemnity was paid. ${ }^{333}$ When Ward formally applied to James I for a pardon, offering a magnificent bribe in exchange for his own amnesty and that of his crew, and promising to return ships, guns, and goods and to

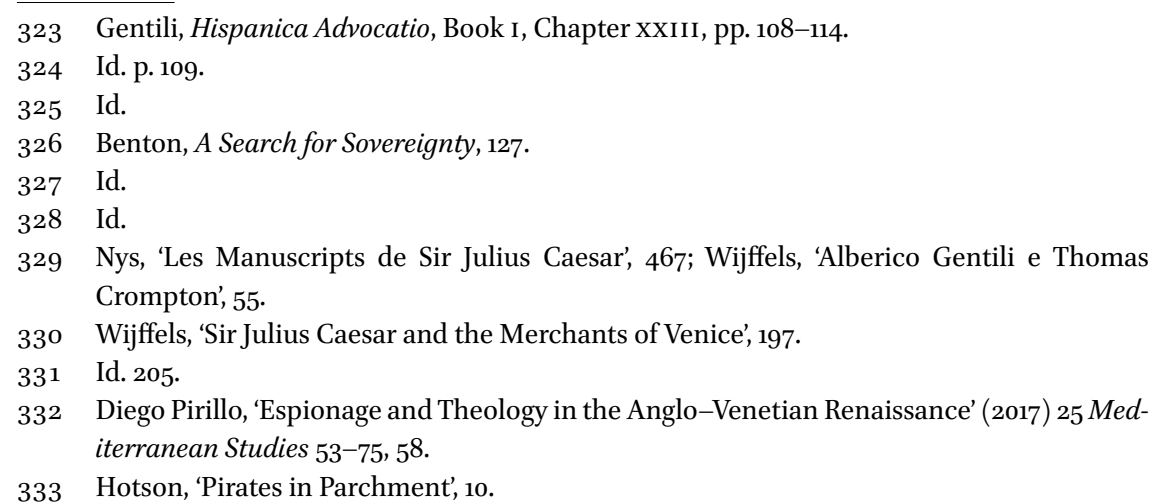


cease all piratical activities, he was neither pardoned nor allowed to return home. ${ }^{334}$

In conclusion, in the early modern period, although the distinction between piracy and privateering was clear in theory, it was fuzzy in practice. In his $A d-$ vocatio Hispanica, Gentili condemned both piracy and privateering as contrary to the law of nations. Based on Cicero and Roman law sources, the concept of the pirate as the enemy of all helped to centralize violence and the consolidation of nation states; it also suspended the application of international law to pirates; and, according to some, facilitated early modern globalization and imperial expansion. ${ }^{335}$

Gentili's positions on the question as to whether the owner who had lost her property through piracy could claim restitution from any other possessor of such goods remained contradictory. In one case, in which he defended Spanish clients, he argued that pirates selling goods did not transfer the property of the same and ruled out acquisition by third parties for lack of good faith. ${ }^{336}$ In the case concerning the Venetian merchants, though, he admitted that the fiscal authorities of Barbary states could transfer title, because of their public function and the good faith of the buyers. ${ }^{337}$ Admittedly, this is not one of the clearest parts of Gentili's work. Possibly, Gentili considered good faith as the distinctive element that justified acquisition of property by third parties. In other words, for Gentili, buyers ought to be in good faith to acquire property from thieves and pirates. ${ }^{338}$ Nonetheless, the quantity of the arguments he deliberately employed to defend his clients make it difficult to ascertain which arguments he ultimately considered superior, and which arguments he merely inserted to create a critical mass of arguments (ad abundantiam) to persuade the Court. It is also unclear whether there were in-depth commonalities among his pleadings or whether he 'did not mind putting his client's interests before everything in the practical application of his principles.'339

\footnotetext{
334 Vitkus, 'Introduction', 27.

335 Policante, The Pirate Myth, xviii.

336 Gentili, Hispanica Advocatio, Book I, Chapters 12 and 15 (noting that pirates captured Spanish ships and sold the cargo to Berbery authorities, which then sold the items to English merchants. Gentili argued that there was no transfer of title and no acquisition of property. Rather, the stolen goods should be returned to the Spanish merchants).

337 Abbott, 'Alberico Gentili and His Advocatio Hispanica', 743.

338 Gentili, Hispanica Advocatio, Book I, Chapter 15, p. 66 (discussing the good faith the buyer ought to show).

Van der Molen, Alberico Gentili and the Development of International Law, 174.
} 


\subsection{Advocacy at the High Court of Admiralty}

In 1605, with the permission of James I, Don Pedro de Zuñiga (1560-1631), the Spanish Ambassador in London, appointed Alberico Gentili as the Advocate of Spain (Advocatus Hispaniorum) at the High Court of Admiralty in London. ${ }^{340}$ Under the 1604 Treaty of London, Spain abandoned any intention to invade England, while England ended its military and financial support of the United Provinces. Because Spain remained at war with the United Provinces, several disputes were brought before the English High Court of Admiralty concerning maritime issues. ${ }^{341}$ Gentili advised on issues concerning neutrality, contraband, privateering, and piracy. ${ }^{342}$

Why did Gentili-a Protestant who was living in exile-agree to defend a Catholic power whose actions he had often criticized in the De Iure Belli? Gentili openly condemned Spanish hegemonic ambitions in his De Iure Belli. England and Spain had been at war for almost two decades, and 'tales of Spanish ... enmity, depicted in art, performed on stage, and recounted in popular literature and pamphlet press' still proliferated. ${ }^{343}$ Moreover, during the same period, the Low Countries had allied with England against the Iberians. Therefore, critics censured Gentili's defence of (Catholic) Spain against the (Protestant) Dutch.

In an unpublished manuscript, dated December 1605, Gentili defended his choice arguing that his previous arguments in the De Iure Belli had been objective. ${ }^{344}$ In De Iure Belli, he criticized Spain for preventing navigation to the new lands. ${ }^{345}$ Analogously, he argued that in his new role as the Advocate of Spain, he was not defending Spain but fighting for truth and justice. ${ }^{346}$ For Spain, the role that Gentili played in the Mendoza affair might have been relevant. As is known, Gentili's theory of state immunity benefitted the Spanish ambassador. Yet, this had occurred twenty years earlier. More likely, the Spanish government appointed him for several good reasons, including his fame, expertise,

340 Kenneth R. Simmonds, 'Un'Opinione Inedita di Alberico Gentili' (1957) 34 Rivista Internazionale di Filosofia del Diritto 83-87, 83 .

341 Nys, 'Les Manuscripts de Sir Julius Caesar', 462.

342 Simmonds, 'Un'Opinione Inedita di Alberico Gentili', 83.

343 Porras, 'Constructing International Law in the East Indian Seas', 782.

344 MS D'Orville 6o8, p. 25.

345 Id.

346 Id. ('Non stamus pro Hispanis nos ... sed pro iustitia ... sacerdotes iustitiae, equum ab iniquo separantes, licitum ab illicito discernentes'.) 
and connections at Court. ${ }^{347}$ At a time in which the English High Court of Admiralty adjudicated delicate matters of international law, and local animosity against Spain remained high after two decades of war, if Spain aimed to successfully defend its claims and win disputes, having one of the best lawyers (princeps fori) would be crucial. Finally, Gentili's representation of the Spanish Embassy matched royal policy. ${ }^{348}$ As the Treaty of London ended the protracted and expensive Anglo-Spanish war, James I saw its implementation as the best guarantee of peace.

In the sixteenth century, the English High Court of Admiralty, which then sat in a former church in Southwark, London, had both administrative and judicial functions. ${ }^{349}$ Not only did it issue letters of reprisals, but it also had both civil and criminal jurisdiction on all shipping and mercantile cases involving English ships or crews at sea, or cases involving foreigners along the English coast. ${ }^{350}$ The Lord Admiral could institute ex officio proceedings against nationals who had disregarded admiralty law, for instance by attacking foreign vessels without a letter of marque. ${ }^{351}$ In parallel, 'foreign merchants, or foreign diplomats on their behalf, could bring actions in the court to reclaim captured property' ${ }^{\prime 32}$ Because of its broad jurisdiction, the High Court of Admiralty did not merely deal with purely national cases; rather, in most cases, it addressed maritime issues of a transnational character.

The High Court of Admiralty operated in a grey area between law and politics. ${ }^{353}$ While the judges of the High Court of Admiralty had to administer justice, ${ }^{354}$ the Court was also subject to certain political, economic, and diplomatic constraints. On the one hand, the admiralty machine was not institutionally independent from the executive power. Admiralty judges were overseen by the Lord Admiral who was a minister of the sovereign. ${ }^{355}$ Moreover, the Lord Admiral and admiralty judges all 'had a material interest in the outcome of the trials'. Whereas the Lord Admiral received a tenth of the value of every prize, the compensation of the admiralty judges was also 'tied to the fees

347 Guido Astuti, 'La Advocatio Hispanica de Alberico Gentili', (1950) Anuario de Historia del Derecho Español 50-69, 53 (adding that 'Gentili performed his duties with diligence, integrity, and care'.)

348 Ian Maclean, Learning and the Marketplace-Essays in the History of the Early Modern Book (Brill: Leiden/Boston 2009) 321.

349 Andrews, Elizabethan Privateering, 23.

350 Id.

351 Id.

352 Id.

353 Hill, Bench and Bureaucracy, xii.

354 Roelofsen, 'Grotius and State Practice of His Day', 24.

355 Hill, Bench and Bureaucracy, 17, 19, and 28. 
and profits of the office.. ${ }^{356}$ Last but not least, the Lord Admiral was also 'a promoter of privateering ventures.' ${ }^{357}$ Therefore, he frequently intervened in cases which directly affected his business and 'he did not hesitate to instruct the judge accordingly'.358 Even when the court granted favourable judgments to strangers, execution of the same would be wanting. 359

On the other hand, in the late sixteenth century, the High Court of Admiralty was at the centre of international politics and diplomacy. ${ }^{360}$ Because most of the maritime disputes adjudicated by the Court inevitably had international implications, the Court was also subject to political and diplomatic interference by the sovereign and the Privy Council for reasons of foreign policy. ${ }^{361}$ Therefore, the Court of Admiralty navigated between the Scylla of economic pressure and the Charybdis of political interference. In conclusion, the court did not meet current standards of independence and impartiality. ${ }^{362}$ Unsurprisingly, in a letter conserved among the D'Orville manuscripts, Gentili 'expressed ... his frustration at the progress of some of the Admiralty proceedings', and accused one of the admiralty judges of partiality. ${ }^{363}$ In the letter, Gentili reported that a judge adjudicated against Spain, as he had done so before in other cases, after committing some procedural errors and rushing to reach his conclusions. ${ }^{364}$ For Gentili, this was manifestly unjust ('sono cose queste tutte manifestamente ingiuste'), but he concluded that this judge would never change ('questo giudice sarà così sempre come è stato sempre'). ${ }^{365}$ In this regard, in his posthumous Hispanica Advocatio, Gentili offered two pearls of wisdom, arguing that 'a judge should guard his reputation by not becoming an advocate', and that 'one ought to avoid and escape by all means ... the judgments of those whom [one] holds in suspicion'. ${ }^{366}$ Nonetheless, the mentioned

\footnotetext{
356 Roelofsen, 'Grotius and State Practice of His Day', 23-24.

357 Andrews, Elizabethan Privateering, 27.

$35^{8}$ Id. 24 .

359 Id. 26 .

360 Hill, Bench and Bureaucracy, 26-27 (noting that the Court 'became an essential agent of English policy'.)

361 Andrews, Elizabethan Privateering, 25 and 27; Hill, Bench and Bureaucracy, 60 (noting that it was not unusual for [admiralty judges] to receive a directive in the Queen's name instructing [them] to show uncommon favor to a particular litigant'.)

362 Hill, Bench and Bureaucracy, xii (highlighting that admiralty judges were 'rarely able to exercise judicial independence'.)

363 Wijffels, Alberico Gentili and Thomas Crompton, 7-8.

364 MS D'Orville 608, 134r.

365 Id.

366 Gentili, Hispanica Advocatio, Book II, Chapter XV, pp. 190-191.
} 
constraints did not prevent the Court of Admiralty from achieving some reasonable outcomes at least for the standards of the period.

Published posthumously in 1613 , the Hispanica Advocatio constituted a major contribution to the emergence of the law of the sea. ${ }^{367}$ It is unique because, up until then, jurists wrote treatises on general subjects or commentaries on particular laws. ${ }^{368}$ Instead, the Hispanica Advocatio is a 'hybrid' work lying in between an academic treatise and a piece of advocacy. ${ }^{369}$ It includes opinions on matters of maritime law, originally written as notes and records of cases in which Gentili appeared as an advocate before the High Court of Admiralty from 1605 up to his death in $1608 .{ }^{370}$ In addition to the opinions in which Gentili defended the interests of Spain, there are opinions in which Gentili defended the interests of English subjects in the context of other maritime disputes, and personal notes destined for other co-counsels or the Spanish Ambassador. ${ }^{371}$ All these different materials concerned similar issues of the law of nations. The Hispanica Advocatio portrays the early modern law of the sea from a bottom up perspective. It shows how given legal principles were applied in practice in the heat of litigation. Not only did it constitute 'the first case-book of the law of nations', but it also contributed to the development of the early modern law of the sea. ${ }^{372}$

Gentili's premature death prevented the completion of the Hispanica Advocatio. As is known, in his will, signed on 14 June 1608, five days before his death, Alberico Gentili asked his brother Scipione to burn all manuscripts except the Hispanica Advocatio. ${ }^{373}$ In Gentili's view, it required some minor editorial work before publication, and he trusted his brother Scipione to undertake this work without too much inconvenience. While Scipione did not burn any of his brother's manuscripts, he did publish the Hispanica Advocatio a few years later for his brother. However, he likely published the manuscript as it stood. ${ }^{374}$ The Hispanica Advocatio constitutes an imperfect recast of the original opinions. ${ }^{375}$ While Alberico Gentili completely rewrote some of his legal opinions, he left

367 Alberico Gentili, Hispanicae Advocationis Libri Duo (Hanoviae: Apud haeredes Guilielmi Antonii 1613); Alberico Gentili, Hispanicae Advocationis Libri Duo, Frank Frost Abbott (trans) (New York: OUP 1921).

368 Abbott, 'Alberico Gentili and His Advocatio Hispanica', 742.

369 Wijffels, 'Sir Julius Caesar's Notes on Admiralty Cases', 100.

370 Simmonds, 'Alberico Gentili at the Admiralty Bar', 4.

371 Astuti, 'La Advocatio Hispanica', 55.

372 Simmonds 'Alberico Gentili at the Admiralty Bar', 22.

373 Simmonds, 'Un'Opinione Inedita di Alberico Gentili', 84.

374 Astuti, 'Di un'Antica Raccolta di Questioni di Diritto Internazionale', 234.

375 Astuti, 'La Advocatio Hispanica', 55. 
others almost unchanged and unintelligible. ${ }^{376}$ The volume also includes some spurious materials concerning matters of civil procedure and civil law. For instance, one legal opinion concerns the admission of Gentili's son, Robert, to the All Souls College, Oxford. ${ }^{377}$ In another unrelated letter, Gentili matter-offactly admits the weakness of his case in one of the disputes before the High Court of Admiralty. It is unlikely that Gentili would have published such letters, if he had the time to finalize his manuscript. He probably envisaged some major rewriting and planned to insert additional materials to the main arguments of the Hispanica Advocatio, but his premature death prevented such revision. ${ }^{378}$ However, not only do these spurious materials contain historical value and contribute to reconstruct some of the disputes, but they also shed light on the dialectical nature of the early modern theory and practice of the law of nations. Nonetheless, the material in the volume is scattered, the sequence of opinions is haphazard, and a final revision by Gentili would have been beneficial.

Whether Gentili aimed to keep the Hispanica Advocatio as a collection of consilia or transform it into a proper treatise, or rather develop it into a collection of pleadings remains uncertain. The form of the Hispanica Advocatio recalls a collection of consilia that was 'an important genre of the Italian method. ${ }^{379}$ Written by eminent jurists, such legal opinions (consilia sapientium) traditionally bridged the gap between theory and practice, idealism and realism, as well as law and politics. ${ }^{380}$ They could be written in defence of a client's interests (pro parte) or constitute an impartial tool to address a given legal issue (pro veritate). In the latter case, the use of legal opinions 'was a strategy, in the absence of an international jurisdictional forum ... to maintain the dispute within relatively peaceful boundaries.' ${ }^{381}$ While most of Gentili's opinions were written pro parte, they did not merely put forward the arguments in favour of his clients; rather, they followed the dialectical method. After briefly describing the facts (casus sic est) and the legal issues (quid iuris) of each case,

376 Astuti, 'La Advocatio Hispanica', 47.

377 Astuti, 'Di un'Antica Raccolta di Questioni di Diritto Internazionale', 230.

378 Id. 232.

379 Alain Wijffels, 'Early-Modern Scholarship on International Law', in Alexander Orakhelashvili (ed.) Research Handbook on the Theory and History of International Law (Cheltenham: EE 2011) 23-60, 30.

380 Silvia Ferretto, 'La Scienza della Politica tra Filosofia e Riflessione Religiosa nella Formazione di Alberico Gentili', in vvaA, Alberico Gentili-Le Marche al Tempo di Alberico Gentili: Religione, Politica, e Cultura (Milano: Giuffrè 2012) 265.

381 Alain Wijffels, 'Alberico Gentili and the Hanse: The Early Reception of the De Iure Belli (1598)', in Pierre-Marie Dupuy and Vincent Chetail (eds.) The Roots of International Law (Leiden: Brill 2014) 181-209, 181. 
Gentili dialectically discussed the possible arguments and counterarguments (disputatio in utramque partem) to reach a given solution (solutio). ${ }^{382} \mathrm{~A}$ diligent and able advocate, Gentili preferred to 'err on the side of completeness' and referred to a vast amount of materials including the civil law, scholarly opinions (opiniones doctorum), and previous decisions (decisiones), as well as historical examples. ${ }^{383}$

Substantively, the Hispanica Advocatio constitutes an imperfect treatise. Gentili structured the various opinions in different chapters according to the various legal topics; while the first book mainly addressed questions of international law, the second book mainly dealt with procedural and other matters. ${ }^{384}$ While Gentili did not produce an organic and unitary treatise, he nonetheless went beyond a mere collection of consilia. ${ }^{385}$ Therefore, the Hispanica Advocatio is not a mere collection of consilia; rather, it constitutes an 'imperfectly systematic treatise'. ${ }^{386}$ Gentili's premature death prevented the completion of 'the ideal final version' of the monograph he had in mind. ${ }^{387}$ Some evidence suggests that had Gentili had more time, he would probably have revised the Hispanica Advocatio and transformed it into a proper treatise. ${ }^{388}$ Confronting the original manuscript with the published version, Wijffels reveals that 'the author first envisaged a conventional collection of consilia' and that only 'at a later stage' did 'he modif[y] the concept of the work'. ${ }^{389}$

The Hispanica Advocatio has also been seen as a collection of pleadings. Wijffels hypothesizes that after first conceiving the Hispanica Advocatio as a collection of consilia, and imagining it as a properly structured treatise, Gentili opted for a middle ground in the form of a collection of pleadings (plaidoyers). ${ }^{390}$ Collections of pleadings were 'a successful genre'; the very title of the Gentilian work, Hispanica Advocatio, which can be translated as pleas of

\footnotetext{
382 Astuti, 'Di un'Antica Raccolta di Questioni di Diritto Internazionale', 235.

383 Id. 236 .

384 Alain Wijffels, 'Alberico Gentili et la Genèse de la Hispanica Advocatio', in vvAA, De la Res Pública a los Estados Modernos-Journées Internationales d'Histoire du Droit (Bilbao: UPV 1992) 299-329, 314.

385 Astuti, 'La Advocatio Hispanica', 55.

386 Wijffels, 'Sir Julius Caesar's Notes on Admiralty Cases', 98.

387 Id. 100.

388 Frank Frost Abbott, 'Translator's Prefatory Remarks', in Alberico Gentili, Hispanicae Advocationis Libri Duo, vol. II, Frank Frost Abbott (transl) (New York: OUP 1921) 9 (noting that had Gentili 'lived to publish the book, very likely ... he would have expanded his summaries into detailed arguments', stated reasons, and completed sentences.)

389 Alain Wijffels, 'Early Modern Literature on International Law and the Usus Modernus' (1995) 16 Grotiana 35-54, 47.

390 Wijffels, 'Sir Julius Caesar's Notes on Admiralty Cases', 111.
} 
Spain, seems to support this theory. ${ }^{391}$ For Wijffels, this literary form allowed for a lively and incisive style and constituted an intermediate approach between the genres of the collection of consilia on the one hand and the treatise on the other. ${ }^{392}$ In any case, the Hispanica Advocatio deliberately has both practical and theoretical relevance. It is also likely that had Gentili had more time, he would have revised it further.

In conclusion, despite some of its perceived limits, including the fragmented and at times contradictory nature of the legal opinions expressed by Gentili, the Hispanica Advocatio remains one of his most important works. It is significant for two reasons. First, it illuminates Gentili's method and his adherence to the Italian style of argumentation (mos italicus). ${ }^{393}$ In the Hispanica Advocatio Gentili used free analogies extensively, transplanting rules from a given legal field to another entirely different sector. ${ }^{394}$ For instance, in addressing the question as to whether a captured ship recovered its freedom when it sailed through neutral waters, one of Gentili's arguments was based on canon law, which held that when a prisoner was on a church's territory, she was no longer subject to sovereign authority. ${ }^{395}$ Gentili drew most of his analogies from civil law, canon law, and medieval commentaries upon the same. ${ }^{396}$ While in other works, he often used biblical, philosophical, and historical sources, non-legal sources are rare in the Hispanica Advocatio, which presents a typically legal discussion. ${ }^{397}$ Therefore, the method Gentili used in his Hispanica Advocatio was similar to that used by contemporary international lawyers.

Second, the Hispanica Advocatio highlights Gentili's contribution to the early modern law of the sea. It examines important questions of both the law of nations in general and the law of the sea in particular. It also sheds some light on key concepts such as the freedom of the high seas, the territorial sea, neutrality, privateering, and piracy. Gentili identified the law of the sea as an important part of the law of nations and conceived the latter as a discipline separate from theology and the civil law. ${ }^{398}$ He often cited civil law, but to 'confir[m] or illustrat [e] rules derived from contemporary usage. ${ }^{399}$ The cases

391 Wijffels, 'Sir Julius Caesar's Notes on Admiralty Cases', 111.

392 Id.

393 Wijffels, 'Early-Modern Literature on International Law and the Usus Modernus', 48.

394 Id.

395 Id.

396 Abbott, 'Translator's Prefatory Remarks', 9.

397 Nussbaum, A Concise History of the Law of Nations, 98.

398 Astuti, 'Di un'Antica Raccolta di Questioni di Diritto Internazionale', 240.

399 Id. 241. 
discussed in the Hispanica Advocatio illuminate the early modern origin of key concepts of the law of the sea. ${ }^{400}$

In conclusion, while the Hispanica Advocatio may not reflect the definitive opinion of Gentili due to the contingent circumstances in which it was written, it certainly sheds light on the historical developments of international law, contributing important insights not only on the law of the sea but also on neutrality law and the law of war. Not only is the Hispanica Advocatio a time capsule and a window into the past, which offers fascinating insights into the living law of maritime disputes and the practical application of the law of nations in the early modern period, but it also offers an engaging discussion of legal issues according to a methodology that remains current nowadays. ${ }^{401}$ For each issue, Gentili examined a range of laws, cases, and authorities both in favour and against his line of argument. It is in the heart of these arguments that the law of nations was shaped and came to life.

\subsection{Critical Assessment}

Gentili greatly contributed to the emergence of the early modern law of nations. While the Gentilian theory has not attracted the interest it deserves, it has contributed key notions to the law of the sea such as the freedom of the seas and the territorial sea and addressed crucial issues such as piracy and privateering. His thinking transcended the so-called battle of the books, which opposed the freedom of the sea to the closure of the same, as his theory contributed to both intellectual currents in equal measure and foreshadowed a vision of the law of the sea that lasted through modernity and still finds mainstream resonance today. Rather than advocating mere protectionism or the absolute freedom of the seas, Gentili identified both polarity and complementarity between freedom and jurisdiction; a common use of natural resources and state sovereignty; and private and public interests in the governance of the sea. More fundamentally, his contribution to the law of the sea should not be seen as a separate chapter of his vast scholarly production; on the contrary, it constitutes one of the pillars of the Gentilian system of international law.

Although the Hispanica Advocatio is often considered to be an unreliable piece of advocacy, its study greatly contributes to the history and theory of international law. This imperfect treatise shows the international practice of the time and the emergence of key concepts of the law of the sea. Although

400 Astuti, 'La Advocatio Hispanica', 57.

401 Id. 67. 
admiralty law has 'never [been] a product of meticulous planning and intense systematic architecture', it has substantively contributed to the creation of important principles of international law, intertwining with the practical application of the same. ${ }^{402}$ Domestic admiralty courts have constituted an important place of international diplomacy and have applied elements of the law of nations. ${ }^{403}$ Gentili's Hispanica Advocatio offers important insights on the functioning of admiralty courts and a lively discussion of key concepts of the law of nations such as the freedom of the sea, territorial sea, neutrality, privateering, and piracy.

Gentili used a dialectical method of argumentation. ${ }^{404} \mathrm{He}$ would first list all of the possible counterarguments that the opponents could raise against his case $^{405}$ Then, he would vigorously put forward the arguments in favour of his case. ${ }^{406}$ His scrutiny tended to be exhaustive. In a note he wrote to a junior counsel, he advised him to carefully consider the legal questions and to deliberately include not only relevant and pertinent arguments, but also additional arguments because they could influence the judge. ${ }^{407}$ These cases show certain inconsistencies in Gentili's arguments with respect to his previous works. ${ }^{408}$ Yet, law is not an exact science and such contradictions probably reflect 'his agility as a lawyer', rather than imperfections of legal reasoning. ${ }^{409}$ Gentili was 'hired to defend Spanish interests with the approval of the English crown', and had to use delicate diplomatic skills in performing his duties. ${ }^{410}$ For Simmonds, this 'may help to explain, if not entirely to excuse, some of the contradictions and uncertainties observed in his pleadings'.411

As a lawyer, Gentili was diligent, skilful, and 'surprisingly successful' ${ }^{412} \mathrm{He}$ exposed his arguments logically with 'vivid forensic skill', constant 'energy', and 'intensity' 413 Although he principally relied on ancient authorities, he 'applied these precedents to the cases before him with a keen awareness of

402 Shavana Musa 'Tides and Tribulations: English Prize Law and the Law of Nations in the Seventeenth Century' (2015) 17 Journal of the History of International Law 47-82, 49.

403 Id. 81.

404 Abbott, 'Alberico Gentili and His Advocatio Hispanica', 746.

405 Id.

406 Id.

407 Id. 747.

408 Benton, 'Legalities of the Sea in Gentili's Hispanica Advocatio', 271.

409 Id. 271-273.

410 Id. 273.

411 Simmonds, 'Alberico Gentili at the Admiralty Bar', 21.

412 Id.

413 Id. 21-22. 
contemporary events and conditions. ${ }^{414}$ He was 'impatient, anxious to dispose of the arguments against him, critical ... of the abilities of the opposing counsel' and 'astute in his use of authorities'. ${ }^{415}$ The Hispanica Advocatio has constituted not only 'a personal record of advocacy' and a vivid example of pleading, but also 'the work of a great jurist'. 416

Because the Hispanica Advocatio 'presents the arguments actually made before the court' and reflects 'the actual application of the principles of international law to concrete cases', not only does it 'throw light on contemporary conditions', but it also illuminates the development of the law of the sea in practice. ${ }^{417}$ In fact, admiralty law 'reflected international law in action'. ${ }^{418}$ The Hispanica Advocatio covers a broader range of maritime questions than the De Iure Belli and constitutes a formidable source of both historical and legal information. From a historical perspective, it offers a nuanced relationship between local historical events and global historical change. It shows us the complex relations among nations in the early modern period, and it does so from a bottom up perspective. It offers a rare window into the culture, the social networks, and legal and diplomatic issues of the time. From a legal perspective, the Hispanica Advocatio exposes the reader to the settlement of contingent maritime disputes and the formation of long-lasting legal concepts. The Hispanica Advocatio provides a rare insight in the way doctrinal theories moved to forensic practice, and, vice versa, precedents contributed to the emergence of general principles of the law of the sea and maritime customs. By illuminating specific legal disputes, and displaying the legal strategies of the parties, not only does the Hispanica Advocatio enable a microhistorical analysis of global phenomena, ${ }^{419}$ but it also shows the coalescence of international law concepts relating to naval warfare and neutrality, piracy and privateering, prize and plunder. The High Court of Admiralty was a socio-legal site, a web of people and practice that contributed to global legal shifts and trends.

Gentili contributed to the elaboration of the binary notions of the freedom of the sea and the territorial sea. For Gentili, the sea was common to all (res communis) and could not be owned. Therefore, if a sovereign restricted others'

\footnotetext{
414 Simmonds, 'Alberico Gentili at the Admiralty Bar', 23.

415 Id. 21-22 (noting that Gentili was 'an extremely able' lawyer 'enjoying the cut and thrust of litigation'.)

416 Id. 22-23.

417 Abbott, 'Alberico Gentili and His Advocatio Hispanica', 742-746.

418 Musa, 'Tides and Tribulations', 82.

419 Valentina Vadi, 'Perspective and Scale in the Architecture of International Legal History' (2019) 30 EJIL 53-71; Valentina Vadi, 'The Power of Scale: International Law and Microhistories' (2018) 46 Denver Journal of International Law and Policy 315-348.
} 
rights to navigate on the high seas, such restriction could serve as a cause of just war. Nonetheless, Gentili also admitted a multi-layered exercise of jurisdiction over the sea. In general terms, states held jurisdiction over the seas to prevent piracy. Gentili defined pirates as the common enemies of humankind. Because pirates violated the law of nations, sovereigns could assert jurisdiction over them, capture, and punish them.

While Gentili thus contributed to the theoretical development of the freedom of the seas, he also conceptualised the notion of territorial sea. For Gentili sovereign jurisdiction extended to proximate seas and in such waters 'the word territory ... applied equally to land and to water. ${ }^{\prime 20} \mathrm{He}$ thus argued that states had full sovereignty and jurisdiction on the territorial sea and that belligerents could not wage war in the territorial waters of a neutral state: let everyone enjoy the use of the sea, but without violating the jurisdiction of another nation. Let everyone remember too that there are limits to a journey by sea as well as to every other journey'.421 In conclusion, while he theorized the freedom of the sea, he also highlighted a number of limits to the same, based on the security of coastal states and of the international community as a whole. For Gentili, the law of nations formed the basis not only for freedom of navigation, but also for multiple forms of jurisdiction over the sea.

The chapter shows that in the early modern period, the oceans were spaces of contention, and non-state actors played a significant role in international legal relations. ${ }^{422}$ The distinction between pirate and privateer was 'not clear or stable. ${ }^{423}$ Gentili considered piracy to be a crime under the law of nations and defined pirates as the common enemy of humankind. ${ }^{424}$ He initially considered privateers as a subsidiary navy but later changed his mind and viewed them as mercenaries of the sea. ${ }^{425}$ Privateering combined trade and plunder, and was 'at the same time both a public and a private undertaking; both domestic and international in its implications. ${ }^{426}$ While during the Elizabethan reign, it was part of the state's military policy, during the Jacobean era,

\footnotetext{
420 Gentili, Hispanica Advocatio, 35 .

421 Id. 38.

422 Michael Kempe, 'Even in the Remotest Corners of the World: Globalized Piracy and International Law, 1500-1900' (2010) 5Journal of Global History 353-372, 353, and 359.

423 Vitkus, 'Introduction', 30.

424 Gentilis, De Iure Belli, Book I, Chapters 4 and 25.

425 Giorgio Badiali, 'Dallo Ius Gentium allo Ius Inter Gentes: il Ruolo di Alberico Gentili agli Albori del Diritto Internazionale Moderno', in Ferdinando Treggiari (ed.) Alberico Gentili-La Tradizione Giuridica Perugina e la Fondazione del Diritto Internazionale (Perugia: Università degli Studi di Perugia 2010) 97.

426 L.M. Hill, 'The Admiralty Circuit of 1591: Some Comments on the Relations between Central Government and Local Interests' (1971) 14 The Historical Journal 3-14, 3.
} 
it was formally condemned. ${ }^{427}$ As more nations began participating in oversea trade, privateering became problematic. ${ }^{428}$ While in his De Iure Belli, Gentili adopted a mild stance acknowledging that letters of sovereigns could play a role in determining whether or not someone was a pirate, ${ }^{429}$ in the Advocatio Hispanica, he aptly noticed this evolution and condemned both piracy and privateering.

\subsection{Conclusions}

In the early modern period, the overseas discoveries altered the spatial vision of the world in fundamental ways and determined a paradigm change in legal theory. ${ }^{430}$ The vastness of the terrestrial sphere, the encounters between different civilizations, and the cultural, commercial, and even violent exchanges among them required new legal frameworks. Connecting Europe, America, Asia, Africa, and Oceania, the oceans were both the place where different civilizations met, clashed, and influenced one another and a 'space of competing legal strategies', a realm in which 'contradictory, mutually exclusive' claims 'competed and collided. ${ }^{431}$ As exploration, navigation, and commerce intensified, the oceans became 'forces of global integration't32 and the law of the sea became more and more central to the creation of an international legal order.

Far from merely meaning a 'free space for commerce' and navigation, ${ }^{433}$ the freedom of the seas transformed the oceans into 'a space of events' of growing intensity and frequency, a great bridge for the movement of ideas, people, capital, and goods, 'a world of mobilities and connections' and 'a context for human activities'.434 The oceans became a space of economic, political, military, and cultural encounters; the freedom of the seas prevailed because it

427 Andrews, Elizabethan Privateering, 235.

428 Peter C. Mancall and Carole Shammas, 'Introduction', in Peter C. Mancall and Carole Shammas (eds) Governing the Sea in the Early Modern Era (San Marino CA: Huntington Library 2015) 1-13, 6.

429 Gentili, De Iure Belli, Book I, Chapter 4, p. 26.

430 Carl Schmitt, Land und Meer. Eine weltgeschichtliche Betrachtung (Leipzig: Verlag von Philipp Reclam 1942).

431 Kempe, 'Globalized Piracy and International Law', 371 and 359.

432 Benton, 'Legal Spaces of Empire', 701.

433 Jones, 'Lines in the Ocean', 317; Carl Schmitt, The Nomos of the Earth in the International Law of the Jus Publicum Europaeum (New York: Telos Press 2003) 43.

434 Jones, 'Lines in the Ocean', 317-319. 
reflected an open, mobile, and changing world. Related to European oversea expansion, ${ }^{435}$ the development of the early modern law of the sea also reflected trade patterns, navigation, and features not only of the Mediterranean Sea but also of other regions of the world. ${ }^{436}$ In parallel, states began asserting territorial rights in their coastal waters to control fisheries and to protect some fundamental interests such as public safety and public health.

Gentili influenced the development of the law of the sea, contributing to the emergence of the key binary concepts of the freedom of the high seas and state sovereignty over the territorial sea. Gentili also addressed issues of naval warfare and neutrality; piracy and privateering; smuggling and the law of finds. Gentili condemned both piracy and privateering as forms of unlawful maritime violence. He defined pirates as enemies of humankind (hostes humani generis) and conceptualized universal jurisdiction to punish them. For Gentili, they lacked the legal protection accorded by domestic and international law, so that everybody could fight them. By committing crimes against the law of nations and engaging in a perpetual war against all, pirates separated themselves from the international community and thus renounced the protection of the law of nations.

Not only did Gentili influence the theory of the debate, but he also engaged with the practice of international law. Often overlooked by scholars because of its practical nature, the Hispanica Advocatio reveals Gentili's active engagement with maritime practice, while it also develops key arguments and theories of the law of the sea. ${ }^{437}$ In the early modern period, the admiralty courts were 'part of a system for governing the oceans', 'a forum for the development of international law in practice', and 'a mechanism for controlling piracy'.438 From a historical perspective, the Hispanica Advocatio constitutes a time capsule, showing us the complex relations among nations in the early modern period from a bottom up perspective. It offers a rare window into the culture, the social networks, and legal and diplomatic issues of the time. From a legal perspective, it illuminates the settlement of contingent maritime disputes, and the formation of enduring legal concepts of the law of the sea.

435 Anghie, Imperialism, Sovereignty and the Making of International Law.

436 Van Ittersum, Profit and Principle, xlv and 1.

437 Benton, 'Piracy and Politics in Gentili's Hispanica Advocatio', 174.

438 Jones, 'Lines in the Ocean', 330; Benton, 'Piracy and Politics in Gentili's Hispanica Advocatio', 187 . 
In elaborating notions that still inform the current law of the sea, Gentili sought to strike a balance between state interests and those of the international community. Gentili's theory and practice regarding the law of the sea was characterized by a singular tension between the differing interests of individual states and those of the international community. Such tension still characterizes the contemporary law of the sea, seeking to endorse delicate equilibrium between particular and common interests. ${ }^{439}$ Gentili also identified a further tension within the early modern law of the sea between the attempts to instrumentalize the law of nations for the pursuit of particular interests and the power of the same to correct or regulate such interests. He resisted the instrumentalization of private maritime violence as a tool of politics and condemned wars of conquest for the pursuit of hegemonic empires.

439 Butler, 'Grotius and the Law of the Sea', 217. 